University of Louisville

ThinkIR: The University of Louisville's Institutional Repository

$5-2016$

\title{
Antibiotic resistant bacteria in natural environments within Kentucky.
}

Steve Tran

University of Louisville

Follow this and additional works at: https://ir.library.louisville.edu/honors

Part of the Biology Commons

\section{Recommended Citation}

Tran, Steve, "Antibiotic resistant bacteria in natural environments within Kentucky." (2016). College of Arts \& Sciences Senior Honors Theses. Paper 122.

http://doi.org/10.18297/honors/122

This Senior Honors Thesis is brought to you for free and open access by the College of Arts \& Sciences at ThinkIR: The University of Louisville's Institutional Repository. It has been accepted for inclusion in College of Arts \& Sciences Senior Honors Theses by an authorized administrator of ThinkIR: The University of Louisville's Institutional Repository. This title appears here courtesy of the author, who has retained all other copyrights. For more information, please contact thinkir@louisville.edu. 


\title{
Antibiotic Resistant Bacteria in Natural Environments within Kentucky
}

\author{
By
}

Steve Tran

Submitted in partial fulfillment of the requirements for Graduation with summa cum laude and for Graduation with Honors

University of Louisville

May, 2016 


\section{Table of Contents}

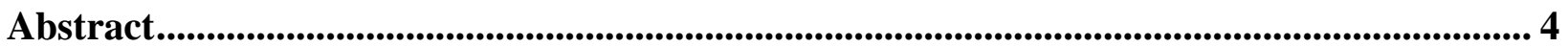

Introduction ................................................................................................................................................... 5

Materials and Methods............................................................................................... 12

Sampling Antibiotic Resistant Bacterial Isolates..................................................................................12

Identification of Resistant Bacterial Isolates..................................................................................................14

Selection and Preparation of Bacterial Isolates ........................................................................................16

Minimum Inhibitory Concentration (MIC) Assay .................................................................................16

Onion Infection Model Assay ................................................................................................................20

Lettuce Infection Model Assay ..................................................................................................................21

Fungal and Bacterial Interaction Assay ………..........................................................................................22

Antibiotic Single Carbon Source Assay ..................................................................................................24

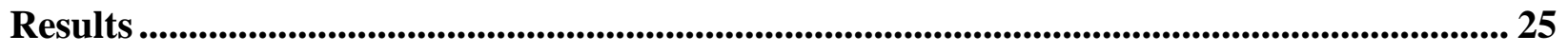

Discovery of Antibiotic Resistant Bacterial Isolates...................................................................................25

Minimum Inhibitory Concentration Assay .................................................................................................2

Plant Model Assay .................................................................................................................................30

Fungal and Bacterial Interaction Assay ..............................................................................................40

Antibiotic Single Carbon Source Assay .....................................................................................................42

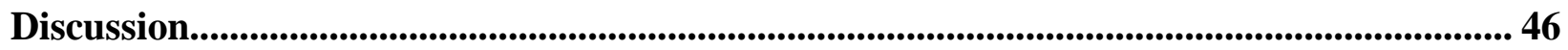

Acknowledgements ..................................................................................................................................... 50

References....................................................................................................................................................... 51

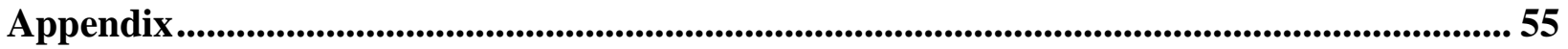


I. Supplementary Figures...................................................................................................................................56

II. Supplementary Tables......................................................................................................................... 63 


\section{Abstract}

Rates of antibiotic resistance in bacteria are rapidly rising; this is, in part, due to overuse of antibiotics resulting in a great burden on the U.S. healthcare system. With the rise of resistant bacteria, a large-scale outbreak of antibiotic resistant bacterial infections may also occur. Research on developing antibiotics has also decreased. Thus healthcare is at a great disadvantage in the arms race against bacteria. The environmental reservoirs of antibiotic resistance are currently being explored in Kentucky, in which bacteria have been collected from a broad spectrum of natural environments to analyze their antibiotic resistant capabilities and their interactions with other environmental organisms. Twenty-seven different genera are represented among 138 antibiotic resistant bacterial isolates collected and ten of the genera are known human pathogens. Experiments on representative isolates were conducted to examine the (i) antibiotic resistance profiles, (ii) ability to consume antibiotics as sole carbon sources, (iii) interaction with two plant models, and (iv) interaction with two fungal species. Results obtained from these experiments showed that a representative bacterial panel of strains had high sensitivities to two of the nine antibiotics tested (rifampicin and tetracycline), and low resistance to one of the antibiotics tested (colistin). However, most of the isolates in our panel were unable to consume antibiotics as a carbon source suggesting that they tolerated the antibiotics rather than metabolized them. Additionally, the interaction between our strain panel and its putative ecological partners showed low levels of pathogenicity in plant models but a differential competitive ability against two fungal strains. These results indicate that our small bacterial representative panel can be used for future studies as they may represent larger populations of native bacteria found in Kentucky. 


\section{Introduction}

Antibiotic resistant bacteria are quickly emerging worldwide due to overuse or misuse of antibiotics. The Centers for Disease Control and Prevention (CDC) has classified a number of bacteria that are becoming resistant to many available antibiotics and potential threats to the U.S. healthcare system, patients, and their families [40]. The quick increase in resistant bacteria is due to the rapid spread of resistance between bacteria over time.

\section{Mechanisms for Antibiotic Resistance Spread}

The emergence of antibiotic resistant bacteria is often due to bacteria obtaining plasmids (or other mobile DNA elements) containing genes whose protein products confer antibiotic resistance. A plasmid is a small, circular, double stranded DNA molecule that is separate from the larger chromosomal DNA within a bacterium. Due to the distinct separation of the chromosomal DNA and plasmid, plasmids are considered to be non-essential for basic cell function but instead offer advantages to survival. For example, plasmids bearing antibiotic resistance cassettes, which are mobile genetic elements that contain genes and recombination sites allowing for genes to be removed or inserted into the cassette and the plasmid itself, may confer resistance to a bacterium in the presence of a specific selective agent. Not only do plasmids sometimes contain antibiotic resistance genes, but they may also contain genes that encode a structure known as a conjugative pilus, which would allow a bacterium to transfer plasmids with another bacterium through a process known as conjugation. Conjugation allows a donor bacterium to distribute plasmids (potentially containing antibiotic resistance cassettes) to neighboring bacteria, therefore making them newly resistant to certain antibiotics [4]. 
Conjugation and other methods for DNA transfer between bacteria [i.e. transformation (uptake of free DNA) or transduction (DNA transferred from bacteriophages)] could result in the emergence of opportunistic, antibiotic resistant bacterial pathogens that could now cause morbidities in humans where initially the bacterial strains were harmless. Not only can it create resistant bacteria but also multi-drug resistant bacteria otherwise known as "super bugs" such as methicillin resistant Staphylococcus aureus (MRSA) or extremely drug resistant (XDR)

Klebsiella pneumoniae [3]. Some strains have even been reported to be pan resistant - resistant to all antibiotics tested [24]. Since many of the opportunistic, antibiotic resistant bacteria causing human infections are genetically distinct rather than clonal, as one would expect from an outbreak spread patient-to-patient, it is highly likely that many of the resistant bacteria are acquired from environmental sources [25].

Pathogenic Gram-negative bacteria are deemed difficult to eradicate due to the unique composition of their cell wall, having an outer and inner membrane, and porins on the outer membrane [36]. The outer membrane allows resistance to many antibiotics that are effective against Gram-positive bacteria. Many Gram-negative bacterial strains are becoming increasingly resistant to many or most available antibiotics; thus placing a great burden on the U.S. healthcare system [40]. Research leading to the development of new antibiotics has also been reduced [10; $29 ; 33$ ] because of the large cost of research, development, and clinical trials.

\section{Cystic Fibrosis and Antibiotic Resistant Pathogens}

Cystic Fibrosis (CF) is a genetic disorder that results in persistent lung infections and leads to gradually decreased capability to breathe in the patient. It is caused by a defect in the human CFTR gene, which encodes a chloride ion transporter. The result of any one of a number 
of potential mutations in this gene is the build-up of viscous mucus on the linings of the lungs and gastrointestinal tract. This sticky mucus is very carbon rich and thus a good food source for bacteria. Patients with CF experience bouts of bacterial pneumonia over the course of their life leading to lung scarring and pulmonary decline. Many people with CF are treated prophylactically and during exacerbation events with high doses of antibiotics [32]. Two particular antibiotics that have been commonly used to treat Gram-negative bacterial infections, specifically in CF patients, are tobramycin and colistin $[5 ; 11 ; 13 ; 20 ; 22 ; 28 ; 32 ; 34]$.

Tobramycin, an aminoglycoside antibiotic that disrupts protein synthesis in bacteria, has been effective at treating Gram-negative bacterial infections [7] and is commonly used to treat CF patients prophylactically through nebulization. Additionally colistin, a polymixin antibiotic that interferes with cell wall synthesis in bacteria, has been reassessed as being an option for treating multi-drug resistant bacterial infections [21] and is a common antibiotic given to CF patients during periods of lung decline due to pneumonia. However, some CF pathogens have the ability to resist tobramycin and/or colistin treatment [5;23].

Resistance to tobramycin can be mediated by two main mechanisms. First, bacteria can alter the permeability of their cell membrane thus leading to a decrease in the uptake of the antibiotic [23; 29]. Mechanisms for impermeability are still undetermined though two proposed mechanisms are alterations in the lipopolysaccharide or changes in outer membrane proteins [23]. Second, tobramycin resistance can evolve through enzymatic modifications of the antibiotic using $N$-acetyltransferases (which catalyze acetyl CoA-dependent acetylations of the antibiotic) and $O$-adenyltransferases (which catalyze ATP-dependent adenylation of tobramycin) - both of which cause a structural modification that prevents the antibiotic from binding to the ribosome [29]. Alteration of the permeability in the membrane is the predominant resistant mechanism 
against tobramycin with a small percentage of the resistant bacterial population having enzyme modification as the resistant mechanism. An even smaller population utilizes both mechanisms for resistance [23].

Resistance to colistin can emerge in several different ways, two of which are similar to tobramycin resistance. One method in resistance is the bacterium's ability to reduce the uptake of the antibiotic by releasing the antibiotic back into the environment quickly with the aid of efflux pumps. Colistin resistance can also be mediated through enzymatic modification of the antibiotic which reduces/prevents it from binding to the target, cellular phospholipids [21]. One unique resistance to colistin not seen in tobramycin resistance is the mutation the ipxA. This gene is essential for biosynthesis of lipid A, which is the precursor for the biosynthesis of lipopolysaccharide that serves as a major component of the outer cell membrane of the Gramnegative bacterium. The mutation leads to absence of production of lipid A and renders colistin ineffective since colistin acts by binding to lipid A in order to function [26]. Though this mutation has only been reported in a few bacteria such as Acinetobacter baumannii [26].

\section{Methods to Studying Antibiotic Resistance}

One common method in assessing a bacterium's susceptibility to an antibiotic is the minimum inhibitory concentration (MIC) assay. An MIC assay is performed by subjecting a bacterial population to decreasing concentrations of an antibiotic. This is normally done in 96well plates that are incubated for 24-48 hours. After the incubation period, the lowest concentration of antibiotic that causes no visible growth of the bacterium in a well is the MIC of the bacterium [15]. MIC is a technique that provides insights into the extent of resistance towards an antibiotic of a bacterial isolate though it is limited because it is based on observable growth. 
For most bacteria, concentrations of up to 100,000 bacterial cells per milliliter are not observable with the naked eye; thus, there may be limited but unobservable growth in a well in response to an antibiotic.

Despite this limitation, the results obtained from an MIC assay can be further interpreted as to how sensitive or susceptible the bacterium is against a particular antibiotic. Once a bacterium has been confirmed as resistant towards a particular antibiotic, the bacterium can be further studied in search of the molecular mechanism that conveys resistance. A common and useful method in closely studying mechanistic steps in resistance would be the use of polymerase chain reaction to identify known antibiotic resistant cassette markers. One limitation of this method, however, is that it will not identify unknown or novel mechanisms.

\section{Other Means to Studying Antibiotic Resistant Environmental Isolates}

What are the ecological roles of these antibiotic resistant bacteria? There are numerous ways to answer this question. This study will focus on the interaction of these isolates with fungi and plants that may occupy the same environmental niche as the bacteria.

Bacteria interact with plants in a variety of ways. Plants and bacteria can form beneficial symbioses such as those rhizobial bacteria that can produce nitrogen-fixing root nodules on the root hairs of leguminous plants. Conversely, the relationship can be adversarial as in the case of plant pathogens. In this case, the bacterium must penetrate the thick plant cell walls in order to cause destruction of tissue and dissemination though the plant. Researchers commonly study plant models such as Arabidopsis or cultivated vegetables to study plant pathogenesis [37]. The latter plant models include using onions or lettuce leaves to simulate live plants in a research laboratory. 
Mechanistic studies have shown that some pathogenic bacteria produce similar subsets of virulence determinants that cause disease in animals and plants [30]. In many cases, plants have evolved defense mechanisms such as the use of phytochemicals to combat pathogenic bacteria that are different from animal defenses. From this, another beneficial use of plant models would be the discovery of a possible source of new therapeutics (i.e. phytochemicals) [30].

Another method to analyze these bacterial isolates would be to study microbial interactions because many of the antimicrobials commonly used in clinics are actually natural products derived from environmental organisms thought by some to be involved in interspecies communication. For example, the genus Streptomyces accounts for $80 \%$ of all antibiotics approved for human use and includes streptomycin, cephalosporins, chloramphenicol, neomycin, tetracycline, nystatin, cycloserine, vancomycin, kanamycin, fosfomycin, and the newer antibiotics daptomycin and platensimycin [31]. Additionally, fungal species can produce antibiotic (e.g. penicillin - described more below). Microbial interaction between microbes can be mutualistic, commensal, competitive, or inhibitory depending on the microbes involved.

In addition to antibiotics produced by fungi, some of the antibiotics that have been used clinically since the 1920's were developed from fungi. Penicillin was discovered and developed from a study of bacterial interactions with the Penicillium genera of fungi [16]. Penicillium species evolved mechanisms to promote survivability, increase competitiveness, or to act as a defense mechanism against other microbes [28]. One mechanism was the secretion of antibacterial compounds, which later evolved into penicillin. There are many fungi that reside in natural environments alongside with bacteria and many of the microbial interactions are competitive or inhibitory. One pathogenic fungus used in this study, Aspergillus fumigatus, has been shown to produce potent antibacterial compounds $[12 ; 38 ; 41]$ and is readily found in the 
soil or decaying organic matter. On the other hand, the human commensal fungus Candida albicans has been shown to work in concert with the human microflora to build biofilms, particularly in the oral cavity [6] but has also been isolated from soils, waters, and in association with plants [27]. This suggests that fungi and microbes can maintain mutualistic relationships as well as competitive/inhibitory relationships; however whether they are actively growing in such environments or are just deposited from animal feces is still unclear.

Another method to analyze these bacterial isolates would be to study the mechanism that conveys resistance. Resistance mechanisms are normally on the molecular level involving changes to certain structures or involving enzymes. Recently, there has been an increase interest in bacteria that are able to not only tolerate the antibiotic but also metabolically consume it. It has been observed that certain clades of bacteria can utilize antibiotics as carbon sources; that is, these bacteria have the ability to consume the antibiotics as food [9]. Growth of a bacterium on the medium containing the antibiotic as a sole carbon source indicates that the bacterium is resistant to the antibiotic and may be either able to breakdown the antibiotic for metabolic consumption or fix $\mathrm{CO}_{2}$ as an autotroph. Fully understanding how the bacterium renders an antibiotic useless or less effective allows researchers to pinpoint and target essential molecular steps in hopes of eradicating or controlling the bacterium.

With the rise of antibiotic resistant bacteria, the push for antibiotic research or treatment against such bacteria must be maintained to prevent continuing instances of pan-resistant organisms and outbreaks. The goals of this study are to investigate the antibiotic resistant capabilities of the bacterial isolates collected in Kentucky and examine the ecological roles of these organisms in their environment. The main hypotheses of this project are that the bacterial isolates obtained in natural environments within Kentucky are resistant to many antibiotics and 
that bacterial isolates found in soil environments will be able to consume antibiotics. We further hypothesize that some bacterial isolates will be plant pathogens and some bacterial isolates will be inhibited by antibacterial compounds produced by the fungi.

\section{Materials and Methods}

\section{Sampling Antibiotic Resistant Bacterial Isolates}

\section{Making LB Agar Plates Containing Antibiotics}

In order to study the bacteria of interest, Lennox LB (Luria-Bertani) agar plates were prepared. Plain Lennox LB agar is a nutrient medium essential for microbial growth and was made by dissolving $35 \mathrm{~g}$ of Lennox LB agar powder (IBI Scientific) into 1 liter of ultrapure water. Lennox LB agar contains $15 \mathrm{~g}$ of agar, $10 \mathrm{~g}$ of tryptone, $5 \mathrm{~g}$ of yeast extract, and $5 \mathrm{~g}$ of sodium chloride per liter. The medium was then autoclaved and placed in a $55^{\circ} \mathrm{C}$ water bath until cooled. To select for only antibiotic resistant bacteria, tobramycin and colistin were added into the medium (to final concentrations of $25 \mathrm{mM}$ and $9 \mathrm{mM}$ for colistin and tobramycin respectively) with swirling to help distribute them evenly. The medium was then poured out into plates and the plates were flipped after solidifying for overnight drying. Flipping the plates prevents possible contamination from water droplets that condenses onto the lid due to the heat from the medium.

\section{$\underline{\text { Sampling and Collecting Bacterial Isolates }}$}

A group of undergraduate and post-bac students and I surveyed natural environments within Kentucky that had a low human activity. The group was divided into four teams, each with a specific natural environment to survey for bacteria (i.e. association with animals or fungi, 
plants, water, and soils). The teams spread out and traveled to different areas within Kentucky stretching east from Louisville to Ashland and south to Elizabethtown (Supplemental Figure 1). Being part of the team to survey plants, our methods in sampling and collecting bacterial isolates were slightly different than the other three teams. Plants were surveyed in multiple different areas in Louisville parks (Supplemental Figure 2). Boston lettuce, broccoli, and an ear of a corn were obtained from groceries procured at a Kroger grocery store (4303 Winston Ave, Convington, KY 41015). The plants chosen were sampled by swabbing the external surfaces with a sterile cotton swab damped with sterile ultrapure water. The swab was then used to inoculate an LB plate supplemented with colistin and tobramycin antibiotics and incubated at $37^{\circ} \mathrm{C}$ in order to grow cultures of the bacteria for further study within the lab.

\section{Determining Resistance to Additional Antibiotics by Plating}

The bacterial isolates that grew on colistin- and tobramycin-containing LB agar plates were transferred to LB agar plates containing up to three additional antibiotics (i.e. carbenicillin, erthryomycin, and irgasan). Plates were made similarly to as described above but with different combination of antibiotics. Plates contained a combination of carbenicillin $(500 \mu \mathrm{g} / \mathrm{mL})$ and irgasan $(25 \mu \mathrm{g} / \mathrm{mL})$; erthryomycin $(500 \mu \mathrm{g} / \mathrm{mL})$ and irgasan $(25 \mu \mathrm{g} / \mathrm{mL})$; or all five antibiotic used thus far. Resistance to these antibiotics was determined by examining the streaked area for visible growth of bacteria. Individual colonies (in contrast to full streaks) were not used as an indication of antibiotic resistance because, individual colonies are more likely the result of mutations in the face of selection than full streaks, which indicates that antibiotic resistance is common among the colonies. 


\section{Identification of Resistant Bacterial Isolates}

\section{Extraction of Genomic DNA from Bacterial Isolates}

Half of the identification was done by a group of undergraduate and graduate students in a summer research lab experience (including myself). The remaining half was done by a post-bac student, Eric Curtsinger, and myself. Genomic DNA (gDNA) was extracted from each bacterial isolate using a DNeasy Blood and Tissue kit (Qiagen). The concentration of each gDNA sample was determined using a Nanodrop 2000 spectrophotometer (Thermo Scientific) at $260 \mathrm{~nm}$. Concentrations were adjusted to $50-600 \mathrm{ng} / \mathrm{mL}$ to ensure that there was enough gDNA for sequence amplification.

\section{Polymerase Chain Reaction of the Small Ribosomal rRNA Gene}

The $16 \mathrm{~S}$ ribosomal rRNA gene was the target for amplification with each isolate gDNA sample. This gene is commonly used to identify bacterial strains [17]. Two different high-fidelity polymerases were used to amplify the $16 \mathrm{~S}$ gene region for each bacterial isolate gDNA sample to increase the accuracy of sequencing. However each halves of the bacterial isolates had a different polymerase. For each gDNA, a master mix was made using the HotStar polymerase (Qiagen). Each reaction (or isolate reaction) contained $10 \mu \mathrm{L}$ of Q-solution, $10 \mu \mathrm{L}$ of $5 \mathrm{x}$ solution, $2 \mu \mathrm{L}$ of upstream 16S universal primer 27F (5'- AGAGTTTGATCMTGGCTCAG -3'; [17]; $10 \mathrm{pmol} / \mu \mathrm{L}), 2 \mu \mathrm{L}$ of $16 \mathrm{~S}$ universal downstream primer $1392 \mathrm{R}\left(5^{\prime}-\right.$ ACGGGCGGTGTGTRC -3'; [17]; $10 \mathrm{pmol} / \mu \mathrm{L}), 1 \mu \mathrm{L}$ of HotStar polymerase (2.5 units/ $\mu \mathrm{L}), 25$ $\mu \mathrm{L}$ of sterile ultrapure water, and $1 \mu \mathrm{L}$ of the template (bacterial gDNA). A second master mix consisted of $10 \mu \mathrm{L}$ of $5 \mathrm{X}$ KAPA solution (KAPA Biosystems), $2 \mu \mathrm{L}$ of upstream primer $27 \mathrm{~F}, 2$ $\mu \mathrm{L}$ of downstream primer $1392 \mathrm{R}, 1 \mu \mathrm{L}$ of KAPA polymerase ( 1 unit/ $\mu \mathrm{L}), 1.5 \mu \mathrm{L}$ of dNTP mix 
(10 mM each) , 33.5 $\mu \mathrm{L}$ of sterile ultrapure water, and $1 \mu \mathrm{L}$ of template. The reactions were then subjected to PCR using different programs for the two polymerases based on manufacturer's recommendations. The program for the PCR reactions with HotStar was: 5 min at $95^{\circ} \mathrm{C} ; 35$ cycles of $1 \mathrm{~min}$ at $94^{\circ} \mathrm{C}, 1 \mathrm{~min}$ at $55^{\circ} \mathrm{C}, 2 \mathrm{~min}$ at $72^{\circ} \mathrm{C} ; 10 \mathrm{~min}$ at $72^{\circ} \mathrm{C}$; and holding at $4{ }^{\circ} \mathrm{C}$. The program for reactions using $\mathrm{KAPA}$ was: $5 \mathrm{~min}$ at $95^{\circ} \mathrm{C} ; 30$ cycles of $1 \mathrm{~min}$ at $98^{\circ} \mathrm{C}, 1 \mathrm{~min}$ at $60^{\circ} \mathrm{C}, 2$ min at $72^{\circ} \mathrm{C} ; 10 \mathrm{~min}$ at $72^{\circ} \mathrm{C}$; and holding at $4^{\circ} \mathrm{C}$. After the PCR programs were completed, the products were electrophoresed on a $1 \%$ agarose gel, and each sample was examined for the presence of a $1400 \mathrm{bp}$ band corresponding to the 16S rRNA gene. Samples containing only one strong band of the proper size were purified using the QIAQuick PCR purification kit (Qiagen) in order to remove any traces of remaining primers, enzymes, and salts prior to sequencing.

\section{$\underline{\text { Sequencing and Identification }}$}

The purified PCR products were sequenced at Macrogen (Baltimore, MD) using the Sanger method to determine the 16S DNA sequences. These DNA sequences were compared to DNA sequences in two databases, GenBank (a national gene and protein database) using the BLAST (Basic Logic Alignment Search Tool) algorithm [1] and the RDP (Ribosomal Database Project, only contains $16 \mathrm{~S}$ gene sequences) [8; 42]. By comparing experimentally determined $16 \mathrm{~S}$ rDNA sequences from the isolates with sequences from databases, the most closely related genus/species for all isolates was established. In all cases, the most closely related species showed at least a $98 \%$ identity to the query sequence suggesting a close match. 


\section{Selection and Preparation of Bacterial Isolates}

Of the 138 bacterial isolates, 36 isolates were chosen to represent the 27 genera to be tested in the MIC assays, lettuce infection assays, fungal-bacterial interaction assays, and antibiotic single carbon source assays. The isolates were selected by choosing 1-3 representative isolates from each of the 27 genera. Genera containing more than five isolates had at least 2-3 representative isolates selected. The classification of the 36 isolates has been abbreviated for simplicity (Supplemental Table 1). Bacterial isolates were prepared by obtaining the isolates from frozen $20 \%$ glycerol stocks and streaking them on LB agar plates. The plates were then incubated at $37^{\circ} \mathrm{C}$ for $24-48$ hours. After incubation plates wrapped with parafilm and stored at room temperature for subsequent experiments.

\section{Minimum Inhibitory Concentration (MIC) Assay}

\section{Preparation of Antibiotic Solutions}

Antibiotic solutions were prepared for use in 96-well plates for the minimum inhibitory concentration assay. Each antibiotic stock solution concentration was $50 \mathrm{mg} / \mathrm{mL}$. Each antibiotic was prepared by dissolving $50 \mathrm{mg}$ of the antibiotic into $1 \mathrm{~mL}$ of an appropriate solvent (Table 1). Antibiotics that were dissolved in water were then filtered through a $22 \mu \mathrm{m}$ syringe filter to ensure sterility. Antibiotic solutions were then aliquoted and stored at $-20^{\circ} \mathrm{C}$. Tubes containing light-sensitive antibiotics were wrapped with aluminum foil to prevent any light-induced degradation. 


\begin{tabular}{|c|c|c|c|c|}
\hline Able 1. Ant & Classification & Mode of Action & $\begin{array}{l}\text { Target Type } \\
\text { of Bacteria }\end{array}$ & $\begin{array}{l}\text { Solvent - } \\
\text { Solubility } \\
(\mathrm{mg} / \mathrm{mL})\end{array}$ \\
\hline $\begin{array}{l}\text { Chloram- } \\
\text { phenicol }\end{array}$ & Others & $\begin{array}{l}\text { Inhibits translation by } \\
\text { blocking peptidyl transferase } \\
\text { on the } 50 \mathrm{~S}\end{array}$ & $\mathrm{G}+$ and G- & Ethanol -50 \\
\hline Colistin & Polypeptides & $\begin{array}{l}\text { Disrupts the outer cell } \\
\text { membrane }\end{array}$ & G- & Water -50 \\
\hline Kanamycin & Aminoglycosides & $\begin{array}{l}\text { Binds to } 70 \mathrm{~S} \text { ribosomal } \\
\text { subunit and inhibits growth of } \\
\text { the bacterium }\end{array}$ & G-, some G+ & Water -50 \\
\hline $\begin{array}{l}\text { Nalidixic } \\
\text { Acid }\end{array}$ & $\begin{array}{l}\text { Quinolones/ } \\
\text { Fluoroquinolone }\end{array}$ & $\begin{array}{l}\text { Interferes with RNA and } \\
\text { protein synthesis }\end{array}$ & $\mathrm{G}+$ and G- & $\begin{array}{c}\text { Chloroform } \\
-50\end{array}$ \\
\hline Penicillin & Penicillin & $\begin{array}{l}\text { Inhibits peptidoglycan } \\
\text { synthesis in cell walls }\end{array}$ & G+ and G- & Water -100 \\
\hline Rifampin & Others & Inhibits RNA polymerase & $\mathrm{G}+$ and G- & $\begin{array}{c}\text { Chloroform } \\
-349\end{array}$ \\
\hline Tetracycline & Tetracyclines & $\begin{array}{l}\text { Inhibits protein synthesis and } \\
\text { ribosomal binding of } \\
\text { aminoacyl-tRNA }\end{array}$ & G+ and G- & Water -50 \\
\hline Tobramycin & Aminoglycosides & $\begin{array}{l}\text { Inhibits formation of the } 70 \mathrm{~S} \\
\text { ribosomal complex }\end{array}$ & G-, some G+ & Water -50 \\
\hline Trimethoprim & Sulfonamides & $\begin{array}{l}\text { Interferes with DNA } \\
\text { synthesis }\end{array}$ & $\mathrm{G}+$ and $\mathrm{G}-$ & DMSO - 50 \\
\hline
\end{tabular}

\section{$\underline{\text { Normalizing Bacterial Isolates }}$}

Since the bacterial isolates used in this study are different in terms of growth rates or cell size, normalizing the bacterial isolates based on culture density allows the MIC data to be compared to one another. Each bacterial isolate was inoculated into a test tube containing $5 \mathrm{~mL}$ LB liquid and incubated at $35-37^{\circ} \mathrm{C}$ on a roller drum for approximately 24 hours. The roller drum allows adequate circulation of nutrient and oxygen within the test tube enabling the bacteria to grow at an optimal rate. After 24 hours, optical densities at $600 \mathrm{~nm}$ (O.D.600) of the liquid cultures were obtained using a BioPhotometer (Eppendorf). Each liquid culture was diluted by a factor of 10 before measuring the O.D.600 (to ensure the reading would be in the 
linear range of the spectrophotometer) by pipetting $100 \mu \mathrm{L}$ of each liquid culture and $900 \mu \mathrm{L}$ of plain LB liquid into each cuvette and mixing to establish a uniform suspension of the bacteria. The spectrophotometer was blanked with plain LB liquid prior to each O.D.600 reading. The desired O.D.600 to normalize all isolates was $1.0 \pm 0.1$ and each isolate was diluted with LB liquid if over that range. No isolates had overnight O.D.600 readings of less than 1.0.

\section{Preparing 96-well Plates for MICs}

Approximately 90 96-well, non-tissue culture treated plates (10 plates for each antibiotic) were prepared in the presence of a nearby lit Bunsen burner. The Bunsen burner was used as a heat barrier to prevent any falling debris or bacteria in the air from contaminating the plates during the preparation. Each plate were prepared by pipetting $200 \mu \mathrm{L}$ of plain LB liquid into each well then an additional $195.9 \mu \mathrm{L}$ into the first row, Row A. Then $4.1 \mu \mathrm{L}$ of a specific antibiotic was pipetted into each well in Row A to achieve a final concentration of $512 \mu \mathrm{g} / \mathrm{mL}$. The concentration of the antibiotic was then serially diluted by transferring $200 \mu \mathrm{L}$ from Row A to Row B with mixing, then $200 \mu \mathrm{L}$ of Row B was transferred to Row C with mixing. This was repeated until Row E where $66 \mu \mathrm{L}$ of Row E was transferred to Row F with mixing then $66 \mu \mathrm{L}$ of Row $\mathrm{F}$ was transferred to Row $\mathrm{G}$ with mixing. Row $\mathrm{H}$ did not contain antibiotics to serve as positive controls for bacterial growth. The final antibiotic concentrations for each row on the 96 well plates were as follows: Row A $(512 \mu \mathrm{g} / \mathrm{mL})$, Row B $(256 \mu \mathrm{g} / \mathrm{mL})$, Row C (128 $\mu \mathrm{g} / \mathrm{mL})$, Row D (64 $\mu \mathrm{g} / \mathrm{mL})$, Row E (32 $\mu \mathrm{g} / \mathrm{mL})$, Row F ( $8 \mu \mathrm{g} / \mathrm{mL})$, Row G ( $2 \mu \mathrm{g} / \mathrm{mL})$, and Row H (0 $\mu \mathrm{g} / \mathrm{mL})$.

\section{Inoculating Plates}


To inoculate each plate, $5 \mu \mathrm{L}$ of each normalized bacterial liquid culture was pipetted in triplicate for each antibiotic to account for biological variability. A Bunsen burner was still used to establish a barrier during inoculation. Positive controls were included on all plates (isolates inoculated into LB with no antibiotics in Row $\mathrm{H}$ of each plate). Negative controls were also included on all plates which was a column consisting only plain LB liquid though, in some cases when the antibiotic stock solution was either cloudy or colored, contained the antibiotic also (e.g. rifampin). After inoculation, the plates were wrapped twice with parafilm to prevent evaporation during incubation. Parafilm seals the plates and can sometimes tear upon even mild heating, resulting in small gaps or openings to the plate; therefore each plate was wrapped twice to prevent any small openings that could cause evaporation. To ensure that the bacterial isolates were not limited for oxygen, two plates were incubated together (one wrapped with parafilm and one not wrapped with parafilm). Both plates had the same bacterial isolates and antibiotics used. The O.D.600 readings for both plates were similar. The volume of solution for the plate with no parafilm did decrease slightly in some wells. Thus the parafilm prevented the loss of solution volume and did not limit oxygen access to the bacterial isolates. A decrease in any well volume would affect the O.D.600 reading during the analysis step by increasing the actual O.D.600 reading due to concentrating the bacterial isolates. Finally, the 96-well plates were incubated for approximately $24-48$ hours at $37^{\circ} \mathrm{C}$ without shaking.

\section{Reading the Plates}

After the incubation period, the plates were removed from the incubator and stripped of the parafilm. The plates were then read using a Sunrise plate reader (Tecan), which measured the O.D.600 of the culture in each well. Each well was scanned 3 times by the machine and the average of each set of readings was given as the output. 


\section{MIC Determination and Statistical Analysis}

To determine the MIC of each antibiotic on each strain, 96-well plates were examined for observable growth. Wells lacking observable growth showed O.D.600 readings between 0 and 0.16 (due to the variation in the background and media and because the spectrophotometer did not allow for blanking the readings) while those showing observable growth had readings above this level. Therefore, we chose 0.16 as the baseline to determine the minimum inhibitory concentration for each replicate in each antibiotic. For each sample, the data were examined for the antibiotic concentration at which the O.D.600 fell below or equally to 0.16 and this was taken as the MIC for that sample. Each antibiotic MIC was then plotted using GraphPad Prism 5 (graphing software).

\section{Onion Infection Model Assay}

Half of the isolates collected by the group of students were also tested in the onion infection assay. The remaining half of the isolates was done with the aid of another post-bac student, Devin McBride, and myself. In preparation, each bacterial isolate was inoculated into a $5 \mathrm{~mL}$ plain $\mathrm{LB}$ liquid test tube and incubated at $35-37^{\circ} \mathrm{C}$ on a roller drum for approximately 24 hours.

\section{Preparing the Onion Material}

Bags of yellow onions were bought from a Kroger grocery store (200 New Albany Plaza, New Albany, IN 47150 and 3165 S $2^{\text {nd }}$ St, Louisville, KY 40208) for this assay. The skin of the onion was removed including the outer layer. The gloves being worn, the onions, and the bench top were sprayed with $70 \%$ ethanol for sterilization. This method was described in Jacobs et al. 
[18]. The onions were cut in quarters with a kitchen knife, which had been disinfected with $70 \%$ ethanol. The layers were then peeled off of one another and cut into approximately 1 inch sections. Only healthy onion peels, indicated by no markings on the peels, were used. The onion peels were placed in an acrylic bin lined with absorbent cloth dampened with sterile water to prevent desiccation of the onion peels. The center of each onion peel was gently pierced with a P200 micropipette tip to serve as the inoculation site.

\section{$\underline{\text { Inoculation and Infection Assay }}$}

Each onion peel was inoculated with $5 \mu \mathrm{L}$ of a designated bacterial liquid culture. Each bacterial isolate were inoculated into three adjacent onion peels to produce triplicates. The acrylic bin was covered with Saran wrap or aluminum foil and incubated at $37^{\circ} \mathrm{C}$ for approximately 48 hours as described in Jacobs et al [18]. The positive control was Burkholderia cepacia strain ATCC 25416 (a known onion pathogen) [18], and the negative controls were Pseudomonas sp. or no bacterial inoculation. The onion peels were photographed every 24 hours. The data obtained were analyzed by comparing pictures of the onion peels before incubation and at the end of the incubation period (Supplementary Figure 3) and rated on a scale of 0 (no maceration) to 3 (massive tissue destruction) based on published protocols [18].

\section{Lettuce Infection Model Assay}

\section{Preparing the Lettuce Material}

Bags of romaine lettuce were bought from a Kroger grocery store $\left(3165 \mathrm{~S} 2^{\text {nd }} \mathrm{St}\right.$, Louisville, KY 40208). All leaves were detached from healthy-looking cores and discarded since the core served as the infection site. The lettuce cores were then washed with $0.1 \%$ bleach and 
rinsed with deionized water twice. The cores were then placed in a bin that has been lined with absorbent cloth soaked in $10 \mathrm{mM}$ magnesium sulfate as described in the Starkey and Laurence protocol [37]. The magnesium sulfate was used to provide humidity within the bin and prevent the lettuce cores from desiccating.

\section{Inoculation and Infection Assay}

Triplicates were made for each bacterial isolate. Each core was inoculated in the center with a designated isolate, from the isolate's LB agar plate, using a toothpick. The positive control was inoculation with Pseudomonas aeruginosa, a known lettuce pathogen [37], and the negative control was not inoculated with a bacterial isolate. The bin was then covered with Saran Wrap to further slow the lettuce cores from drying out. The bin was then incubated at $30^{\circ} \mathrm{C}$ for five days. Throughout the course of the incubation period, the absorbent cloth was kept damp with magnesium sulfate and the lettuce cores were photographed each day and six hours later each day for five days. The data obtained were analyzed by comparing pictures of the lettuce core before incubation and at the end of the incubation period (Supplementary Figure 4). Rating based on maceration level was done by assigning the negative control a score of 0 , the positive control a score of 3, and any intermediate maceration in-between the two mentioned scores was determined subjectively.

\section{Fungal and Bacterial Interaction Assay}

\section{Making Yeast Peptone Dextrose (YPD) Agar Plates}

YPD plates were used in this experiment to allow the growth of fungi on agar plates. YPD plates were made by dissolving $10 \mathrm{~g}$ yeast extract, $20 \mathrm{~g}$ bacterial peptone, $20 \mathrm{~g}$ glucose or dextrose, and $15 \mathrm{~g}$ bacto agar into $1 \mathrm{~L}$ of ultrapure water. The medium was then mixed 
thoroughly, autoclaved, and placed in a $55^{\circ} \mathrm{C}$ water bath to cool. Then the medium was poured into petri dishes where it was left to cool on the bench top. Finally after the medium had solidified, the plates were flipped and left for overnight drying.

\section{$\underline{\text { Inoculation of Fungi and Bacterial Isolates }}$}

The fungi used in this study were Aspergillus fumigatus (ATCC B5852) and Candida albicans (ATCC 23R). The inoculation process involved making three long streaks, which were evenly spaced, of one of the fungi on a standard 100 millimeter YPD agar plate. Then three short streaks of a designated bacterial isolate were made to be perpendicular to the three long fungus streaks using sterile applicators between streaks; therefore it would appear that there were three intersections of the streaks made representing triplicates of the bacteria isolate (for example, see

Supplementary Figure 5). This method was done for all isolates and the overall procedure was repeated for the other fungus. The plates were then incubated for approximately 24 hours at $37^{\circ} \mathrm{C}$. The procedure was then performed again but this time the three long streaks were streaked from a bacterial isolate and the three short perpendicular streaks were streaked from a fungus. This was done for all bacterial isolates. The two fungi were also plated individually to serve as positive controls. Positive controls for all of the isolates were also streaked on separate plates.

\section{Analyzing the Interactions}

After the incubation period, the plates were examined to see the interaction between the fungi and the bacteria. Controls were used to compare the interaction to see which microbe (i.e. fungus or bacterium) outcompeted or inhibited the other since some bacteria looked similar to one of the fungi. The interactions between microbes were determined by closely examining the 
intersection between the streaks of two different microbes. Normally when microbes grow after being streaked on a petri dish, they grow in a solid line filling the indention of the streak. Upon examining the intersection, if the fungal streak was not disrupted by the bacterial streak, then the fungus outcompeted or inhibited the bacteria. If the bacterial streak was not disrupted by the fungal streak, then the bacterium outcompeted or inhibited the fungus.

\section{Antibiotic Single Carbon Source Assay}

\section{Making Antibiotic Single Carbon Source (Ab SCS) Plates}

Ab SCS plates were made by dissolving $40 \mathrm{mM}$ ammonium sulfate, $20 \mathrm{mM}$ monopotassium phosphate, $2 \mathrm{mM}$ magnesium sulfate heptahydrate, $0.040 \mathrm{mM}$ sodium EDTA, $0.016 \mathrm{mM}$ zinc sulfate heptahydrate, $0.031 \mathrm{mM}$ calcium chloride dihydrate, $0.01 \mathrm{mM}$ iron sulfate heptahydrate, $0.005 \mathrm{mM}$ manganese chloride tetrahydrate, $0.02 \mathrm{mM}$ boric acid, $0.002 \mathrm{mM}$ sodium molybdate dihydrate, $0.001 \mathrm{mM}$ copper sulfate pentahydrate, $0.001 \mathrm{mM}$ cobalt chloride hexahydrate, and $0.0006 \mathrm{mM}$ potassium iodide into 1L of ultrapure water [9]. Some chemical ingredients were unable to be accurately measured out on the scale due to the scale's ability to measure only to $1 \mathrm{mg}$; therefore any ingredient under $1 \mathrm{mg}$ were measured out by dissolving a single crystal of the certain compound or just enough that was below $1 \mathrm{mg}$. The $\mathrm{pH}$ of the solution was adjusted to approximately 5.5 using hydrochloric acid then the mixture was sterilized through a $0.22 \mu \mathrm{m}$ filter into two $500 \mathrm{~mL}$ glass bottles. Then $7.5 \mathrm{~g}$ of plain Lennox LB agar powder was dissolved into each bottle, the medium was autoclaved, and it was placed in a $55^{\circ} \mathrm{C}$ water bath to cool. Once cooled, $0.5 \mathrm{~g}$ of a specific antibiotic was dissolved into one 500 $\mathrm{mL}$ bottle. The medium was poured out into plates and cooled on the lab bench top until the agar 
had solidified. The plates were then flipped for overnight drying. It should be noted that only 0.1 $\mathrm{g}$ of colistin was added due to availability and cost of colistin.

\section{Streaking the Ab SCS Plates}

Plates were divided into eight regions. Eight isolates were plated in replicate onto three individual plates (for triplicates) and the process was repeated until all 35 isolates were streaked onto three plates each. Escherichia coli K12 was also plated on each of the nine Ab SCS plate as a negative control to ensure the media were made correctly (E. coli $\mathrm{K} 12$ is susceptible to many antibiotics). The plates were then incubated under $37^{\circ} \mathrm{C}$ for approximately 24 hours.

\section{Results}

\section{Discovery of Antibiotic Resistant Bacterial Isolates}

Approximately 162 bacterial isolates were collected for this project (i.e. 38 from animals/fungi, 44 from water, 35 from plants, and 45 from soils) but only approximately 138 of the isolates could be re-grown from freezer stocks and appeared to maintain their resistance to colistin or tobramycin. The original goal of the project was to identify specific pathogens which were resistant to either carbenicillin and irgasan (for Stenotrophomonas maltophilia) or erthryomycin and irgasan (for Burkholderia cepacia complex strains), so the ability of these isolates to resist these combinations was tested. Out of these 138 isolates, only 12 were resistant to a combination of carbenicillin and irgasan, 24 were resistant to a combination of erythromycin and irgasan, and 8 were resistant to all five antibiotics as shown in Figure 1. These results showed that majority of the isolates are resistant to colistin and tobramycin with a few isolates 
resistant to other antibiotic combinations. If tested with single antibiotics (i.e. just carbenicillin or just irgasan), the isolates may have shown a greater response in resistance.

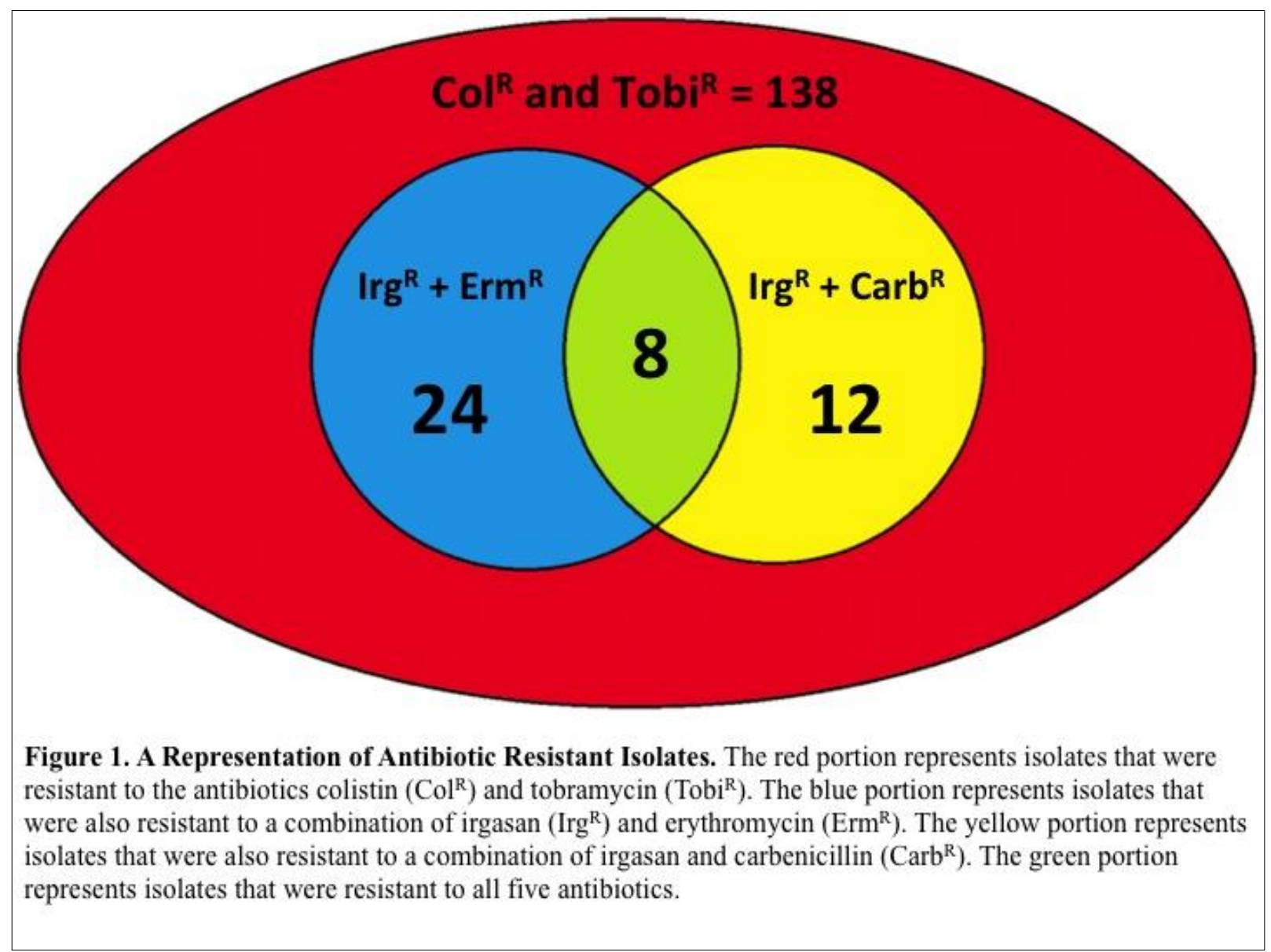

\section{Bacterial Species/Genus Identification}

The genus/species for each cultured isolates was determined by amplification of the $16 \mathrm{~S}$ rRNA gene and comparison to online databases. For most of the isolates, the e-value from GenBank (a national gene and protein database) was 0 indicating a strong similarity to known isolates. Similarly, the results from the RDP (Ribosomal Database Project, only contains 16S gene sequences) show a strong indication of a single genera or species associated with each isolate (i.e. most isolates had a $100 \%$ confidence level). The genus identification of some isolates were slightly unclear due to having a low RDP confidence level (CL) such as Aminobacterium 
$(\mathrm{CL}=33 \%)$, Unclassified Microbacteriacea $(\mathrm{CL}=46 \%)$ and Falsibacillus $(\mathrm{CL}=30 \%)$. The 138 isolates represented 27 different genera in which 10 of the genera are known to contain human pathogens [14]. The ten genera that contain pathogenic species are Aeromonas, Bacillus, Burkholderia, Enterococcus, Morganella, Providencia, Pseudomonas, Rhodococcus, Serratia, and Stenotrophomonas.

The most predominant genus present in all four mentioned types of environments was Serratia, a Gram-negative bacterium (Table 2). Also found in high abundance were Bacillus species, Spingobacterium species, and Paenibacillus species. Other genera were found less frequently. This indicates that there are some species which are more prevalent and might be considered ecological generalists while others may be more specialists for an environment. These conclusions should be tempered because of sampling bias in siles, samples, environments, and due to the specific media that was employed and limited sample number. The resultant organisms might be of interest as they might be reservoirs of antibiotic resistance. Further, they may represent rare but emerging opportunistic pathogens in veterinary, agricultural, or human infections. Thus, further testing was warranted.

\section{Minimum Inhibitory Concentration Assay}

The goal of the MIC assays was to assess the representative isolates' resistant profile to the nine antibiotics. Antibiotics were chosen for this assay based on mode of action and classification to ensure a broad diversity of antibacterial agents (Table 1). The hypothesis was that many of the isolates would be resistant to antibiotics other than tobramycin and colistin. To establish whether the isolate collection was resistant only to tobramycin and colistin or broadly 


\begin{tabular}{|c|c|c|c|}
\hline Bacterial Genus & $\begin{array}{c}\text { Number of } \\
\text { Isolates }\end{array}$ & Isolated From & Gram Stain \\
\hline Aeromonas & 6 & Waters & - \\
\hline Arthrobacter & 3 & Soils & + \\
\hline Bacillus & 23 & Waters, Soils, Insects, Fungi & + \\
\hline Brevibacillus & 8 & Water, Soil, Insects & + \\
\hline Burkholderia & 4 & Soils & - \\
\hline Cellulosimicrobium & 1 & Soil & + \\
\hline Chromobacterium & 1 & Water & - \\
\hline Chryseobacterium & 10 & Water, Plants & - \\
\hline Cloacibacterium & 1 & Water & - \\
\hline Elizabethkingia & 1 & Soil & - \\
\hline Empedobacter & 1 & Water & - \\
\hline Enterococcus & 2 & Animal feces & + \\
\hline Flavobacterium & 1 & Water & - \\
\hline Leucobacter & 1 & Plant & + \\
\hline Microbacterium & 8 & Water, Plant, Soils & + \\
\hline Morganella & 2 & Water & - \\
\hline Myroides & 1 & Insect & - \\
\hline Paenibacillus & 10 & Soils, Waters, Plants & + \\
\hline Providencia & 4 & Plants & - \\
\hline Pseudochrobacterum & 2 & Soils & - \\
\hline Pseudomonas & 2 & Plants & - \\
\hline Rhodococcus & 1 & Soil & + \\
\hline Serratia & 31 & Plants, Soils, Fungi, Water & - \\
\hline Sphingobacterium & 13 & Water, Soil, Insects & - \\
\hline Stenotrophomonas & 1 & Soil & - \\
\hline Total & 138 & & \\
\hline
\end{tabular}

to many antibiotics, each representative isolate were inoculated into 96 well plates containing serially diluted antibiotics. The antibiotics used in this study were chosen for their breadth in terms of their mechanism of action and the types of bacteria they are known to inhibit (Table 1). For the genera with an abundance of isolates (e.g. Bacillus, Serratia, and Sphingobacterium -

Table 2), 2-3 representative isolates were used. The results are shown in Table 3. 
A low MIC reveals that a bacterium is highly susceptible to the antibiotic and a high MIC could be interpreted as a low sensitivity or complete resistance against the antibiotic. Most isolates that were subjected to colistin, penicillin, tobramycin, or trimethoprim were highly resistant to these antibiotics with MICs greater than $512 \mu \mathrm{g} / \mathrm{mL}$ (indicated with “**” in Table 3), which indicates that they are resistant to all concentrations tested. Most of the isolates that were subjected with chloramphenicol, kanamycin, and nalidixic acid had many MIC values in the low to intermediate range (i.e. values in the range of $2-512 \mu \mathrm{g} / \mathrm{mL}$ ). Most isolates that were subjected with rifampin and tetracycline had low MIC values (i.e. values in less than $64 \mu \mathrm{g} / \mathrm{mL}$ ), which indicate little resistance to these antibiotics in these natural isolates.

\begin{tabular}{|c|c|c|c|c|c|c|c|c|c|}
\hline \multirow[b]{2}{*}{ Bacterial Isolates } & \multicolumn{9}{|c|}{ Antibiotics $(\mu \mathrm{g} / \mathrm{mL})$} \\
\hline & Chloramphenicol & Colisitin & \begin{tabular}{|l|} 
Kanamycin \\
\end{tabular} & Nalidixic Acid & Penicillin & Rifampin & Tetracycline & \begin{tabular}{|l|} 
Tobramycin \\
\end{tabular} & Trimethoprim \\
\hline Aeromonas caviae & 2 & 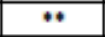 & 2 & 2 & 2 & 2 & 2 & 32 & 32 \\
\hline Aeromonas hydrophila & 8 & ${ }^{*} 512$ & 256 & 128 & 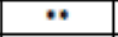 & 8 & 2 & 32 & $*$ \\
\hline Aminobacterium & 64 & 512 & 512 & 256 & $\cdots$ & 8 & 64 & 64 & 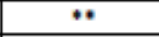 \\
\hline Arthrobacter nitroguajacolicus & 32 & 512 & $* 512$ & 64 & $\cdots$ & 256 & +128 & ${ }^{*} 64$ & 2 \\
\hline Bacillus cereus & •128 & $*$ & 64 & 64 & $\cdots$ & 32 & 2 & 32 & 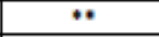 \\
\hline Bacillus thuringiensis, -anthracis, -cereus & 8 & 512 & 128 & 128 & 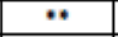 & 8 & 2 & 32 & $*$ \\
\hline Bacillus thuringiensis, -cereus, -toyonensis & 8 & $*$ & $\bullet 512$ & 32 & $\cdots$ & 2 & 8 & 64 & 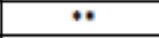 \\
\hline Brevibacillus laterosporus & 512 & 512 & 32 & 256 & 2 & 2 & 8 & 8 & 2 \\
\hline Brevibacillus reuszeri, -choshinensis, -brevis & 8 & $*$ & $\cdot 512$ & 256 & •256 & 2 & "8 & $\cdot 256$ & 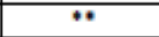 \\
\hline Burkholderia cepacia & 8 & 5512 & 5512 & 128 & $\cdots$ & 8 & 8 & 256 & $\cdots$ \\
\hline Cellulosimicrobium funkei, -cellulans & 8 & 256 & 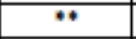 & 256 & 32 & 2 & 2 & $\bullet$ & 32 \\
\hline Chromobacterium aquaticum & 32 & $+*$ & 64 & 128 & $\cdots$ & 64 & 2 & 64 & 8 \\
\hline Chryseobacterium letacus & 8 & 512 & 32 & 64 & 512 & 2 & 2 & 32 & 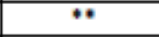 \\
\hline Chryseobacterium stagni, -gambrini & 128 & +4 & "64 & 64 & $\cdots$ & 256 & +128 & ${ }^{\circ} 64$ & +2 \\
\hline Cloacibacterium sp./unknown & 8 & ${ }^{*} 256$ & 8 & 256 & 8 & 32 & 8 & 8 & 2 \\
\hline Elizabethkingia meningoseptica, -anophelis & 64 & $+*$ & 256 & 256 & 512 & 2 & 128 & 512 & 32 \\
\hline Empedobacter brevis & 32 & ${ }^{*} 512$ & $\cdot 256$ & ${ }^{*} 256$ & +512 & 8 & $\bullet 32$ & $*$ & 32 \\
\hline Enterococcus casseliflavus, -gallinarum & 32 & 512 & 2 & 2 & 2 & 2 & 2 & 8 & 2 \\
\hline Falsibacillus & 32 & $*$ & $\bullet 512$ & 128 & +512 & 2 & 64 & 256 & 8 \\
\hline Flavobacterium sp. & 32 & $*$ & 512 & 128 & 32 & 2 & 8 & 512 & $*$ \\
\hline Leucobacter chromiireducens & $* 256$ & 256 & $\bullet 512$ & 256 & 512 & 2 & 8 & $*$ & 32 \\
\hline Microbacterium arborescens & 64 & $* *$ & $\cdot 256$ & $*$ & .32 & 2 & 48 & ${ }^{*} 64$ & $*$ \\
\hline Morganella morganii & 8 & $*$ & "64 & 32 & $\cdots$ & 2 & 2 & 32 & $*$ \\
\hline Myroides odoratus & 256 & $* 4$ & $*$ & 128 & 512 & 32 & 2 & $*$ & 256 \\
\hline Paenibacillus alvei & 2 & ${ }^{* 512}$ & .512 & 32 & $\cdots$ & 2 & 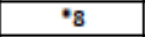 & $\cdot 256$ & 5512 \\
\hline Paenibacillus apiarius & 32 & $* 512$ & $\cdot 512$ & 8 & 8 & 2 & 2 & 128 & 32 \\
\hline Providencia & 512 & 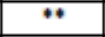 & 64 & ${ }^{*} 256$ & $\cdots$ & 256 & 64 & 64 & 8 \\
\hline Pseudochrobactrum asaccharolyticum, -saccharolyticum & 8 & 512 & 128 & 64 & 512 & 64 & 32 & 64 & 128 \\
\hline Pseudomonas protegens & 8 & 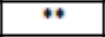 & $*$ & 128 & 512 & 2 & 32 & $*$ & 8 \\
\hline Rhodococcus equi & 8 & 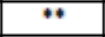 & $\cdot 512$ & 64 & $\cdots$ & 8 & ${ }^{\circ} 64$ & $\cdot 256$ & 48 \\
\hline Serratia marcescens & 128 & 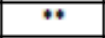 & 512 & 256 & $\cdots$ & 512 & 64 & 64 & 8 \\
\hline Serratio marcescens & 32 & +4 & 512 & 64 & $\cdots$ & 256 & 64 & 64 & 8 \\
\hline Serratia marcescens, -nematodiphila & *64 & $\bullet$ & 512 & 64 & $\cdots$ & $\cdot 256$ & 64 & 128 & 8 \\
\hline Sphingobocterium foecium & 32 & 256 & 256 & 32 & $\cdots$ & 2 & 2 & 128 & $*$ \\
\hline Sphingobacterium siyangensis, -multivorum & $*$ & $*$ & $*$ & 128 & ${ }^{*} 64$ & 2 & ${ }^{\circ} 64$ & $\bullet$ & $\cdot 2$ \\
\hline \multicolumn{10}{|c|}{$\begin{array}{l}\text { *One or two trials had MIC higher than } 512 \mu \mathrm{g} / \mathrm{mL} \\
* \text { All three tirals had MIC higher than } 512 \mu \mathrm{g} / \mathrm{mL} \\
\cdots * \text { Values from the table represent the median value from triplicate samples }\end{array}$} \\
\hline
\end{tabular}


The dynamics of the interaction between each representative bacterial strain and antibiotic is illustrated in Figures 2-10. For each antibiotic, seven strains were analyzed together in the same plot to avoid confusion and were combined alphabetically. Each graph within each figure tends to show a consistent pattern for most of the isolates for each antibiotic (e.g. most isolates in Figure 2 show a negative relationship between growth and increasing antibiotic concentration). The antibiotics chloramphenicol, nalidixic acid, and rifampin showed drastic decreases in O.D.600 levels for most isolates as antibiotic concentration increased especially at low concentrations. The antibiotics colistin, kanamycin, penicillin, tetracycline, and tobramycin showed small decreases growth for most isolates but also a small increase in O.D.600 level for a few isolates as antibiotic concentration increased. Trimethoprim showed a unique set of MIC results in that more isolates than anticipated had an increasing O.D.600 level as antibiotic concentration increased (Figure 10).

\section{Plant Model Assay}

Bacteria in the soil can be beneficial to plants by protecting them against pathogens or by fixing nitrogen from the air which is necessary for plant growth. Bacteria can also be plant pathogens and can infect the roots, stems, and leaves of plants. The goal of this assay was to determine the pathogenicity of the representative isolates towards onions and lettuce. The hypothesis of this assay was that some of the isolates were pathogenic to these two plant models. To test the pathogenicity of the representative panel isolates for the ability to cause pathogenesis in two plant models - onion bulb and lettuce leaves, the isolates were inoculated into sterile onion peels and lettuce cores as described in the Materials and Methods section according to published protocols [18, 37]. 


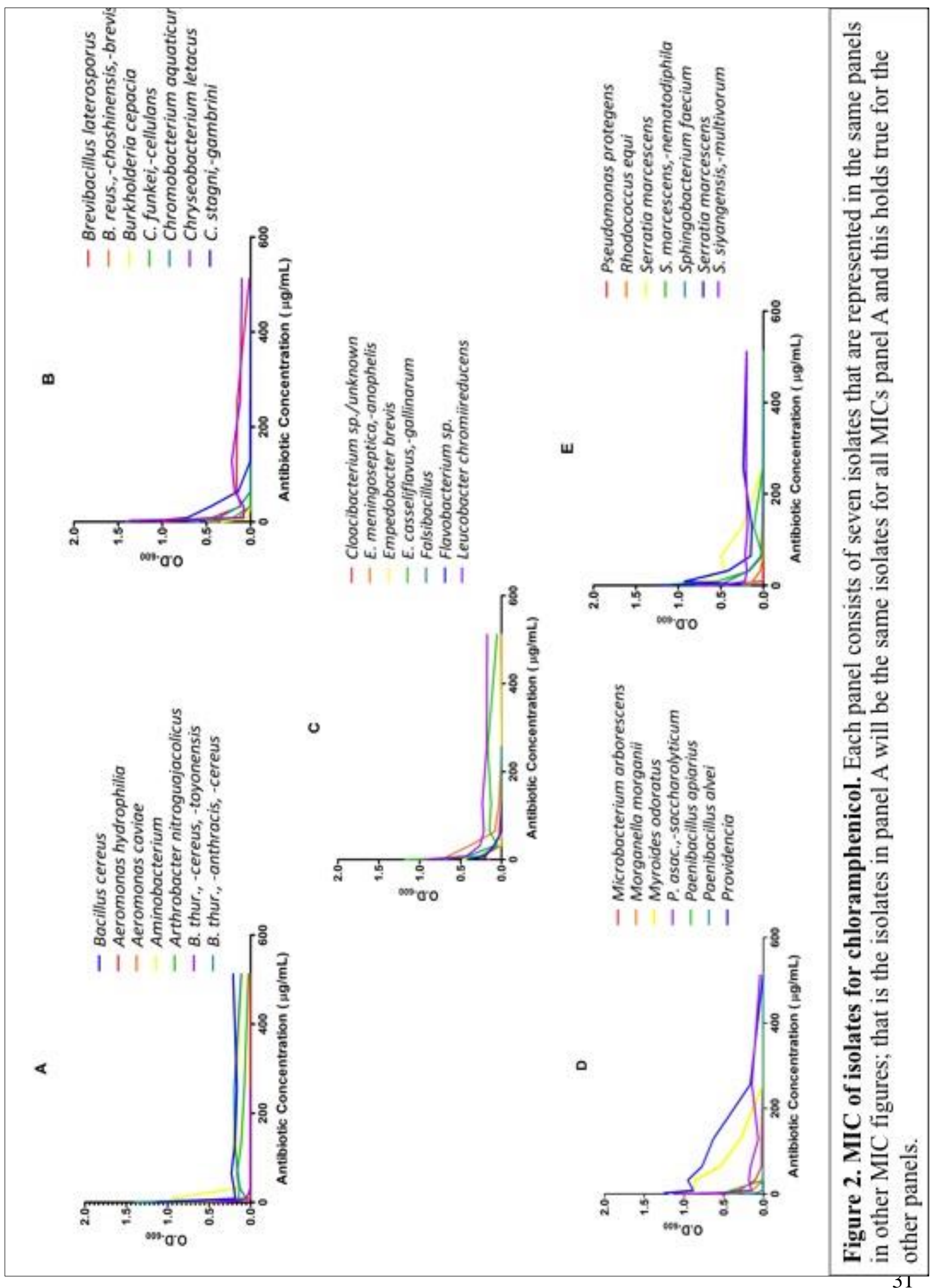




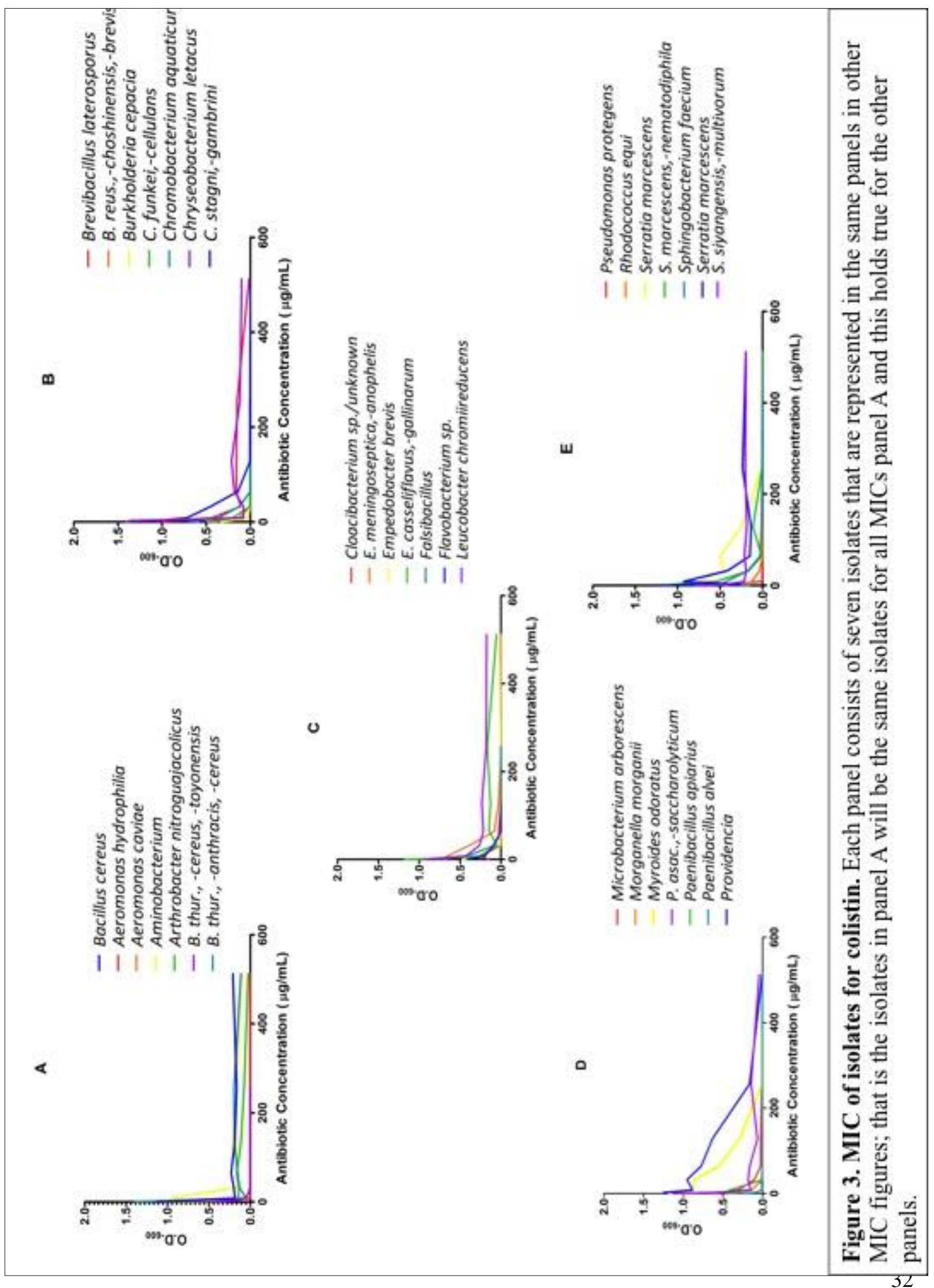




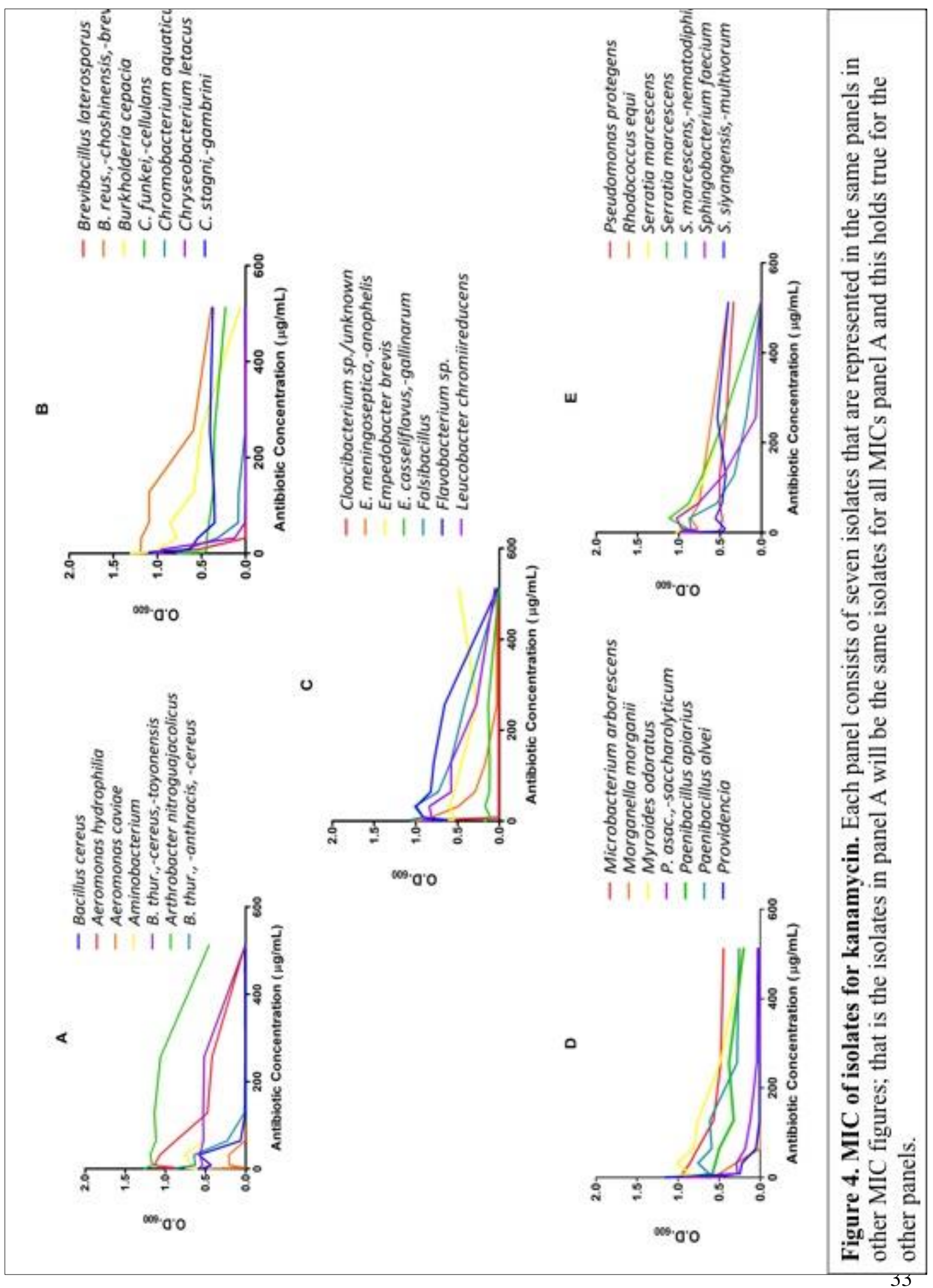




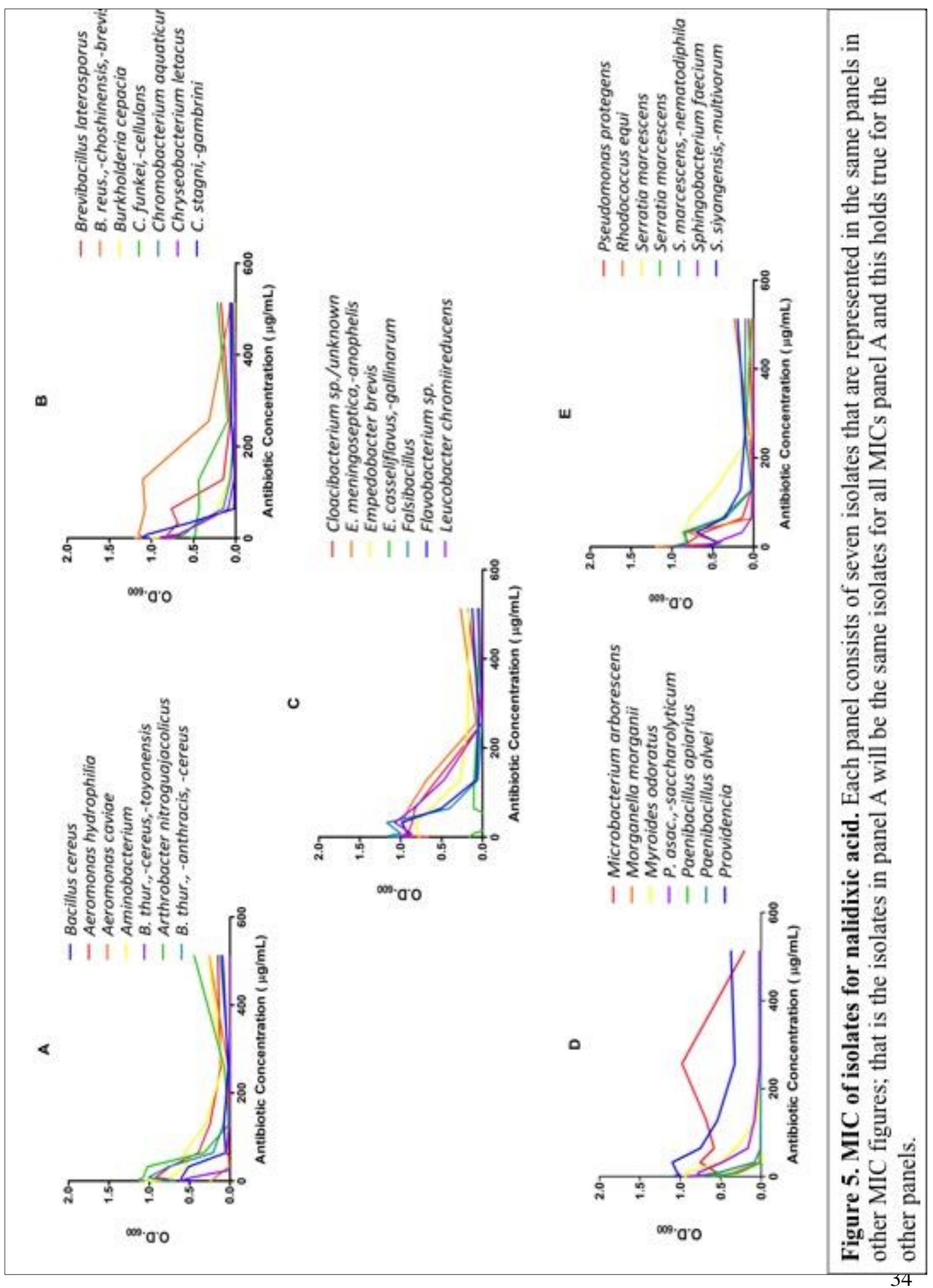




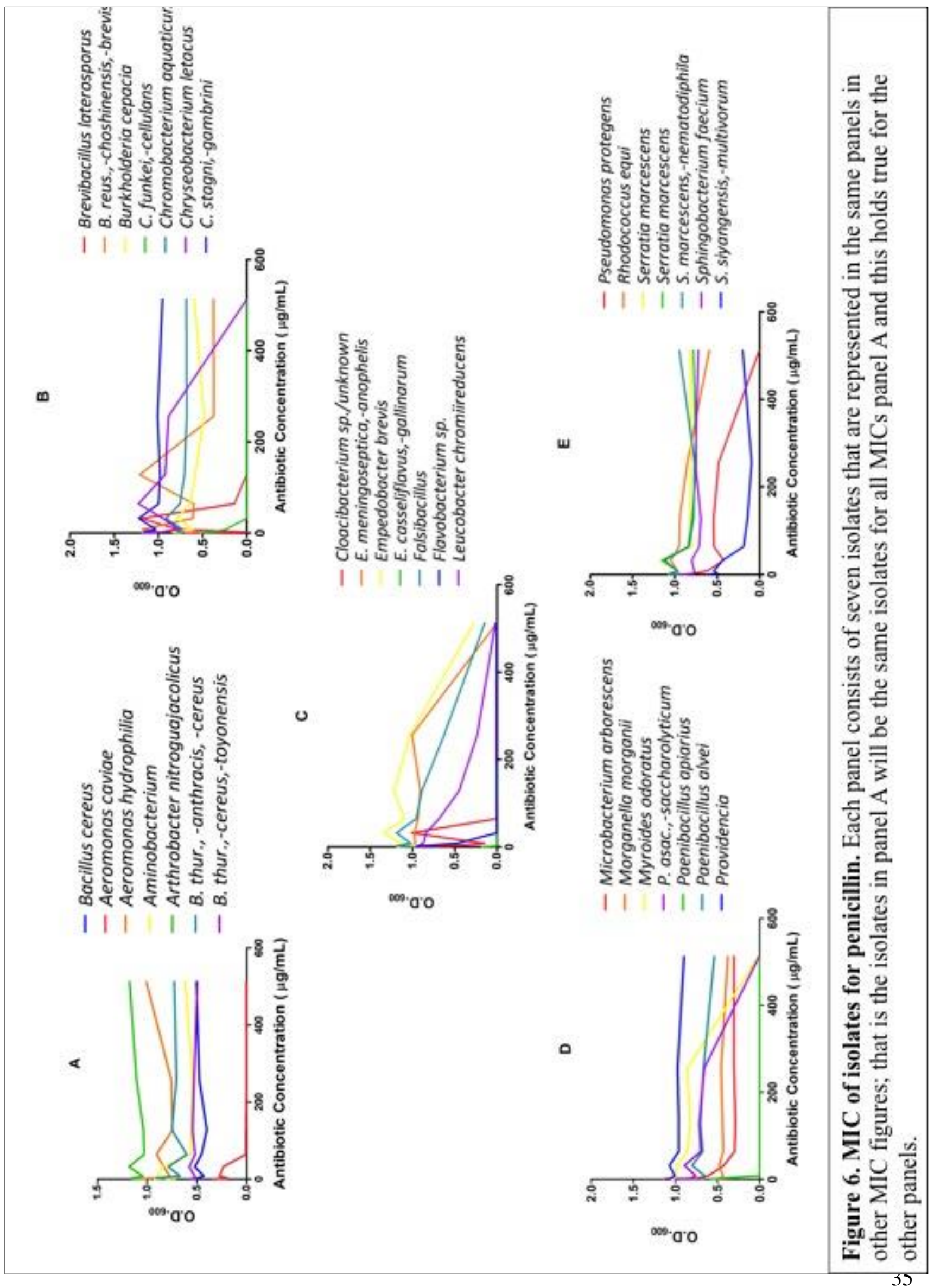




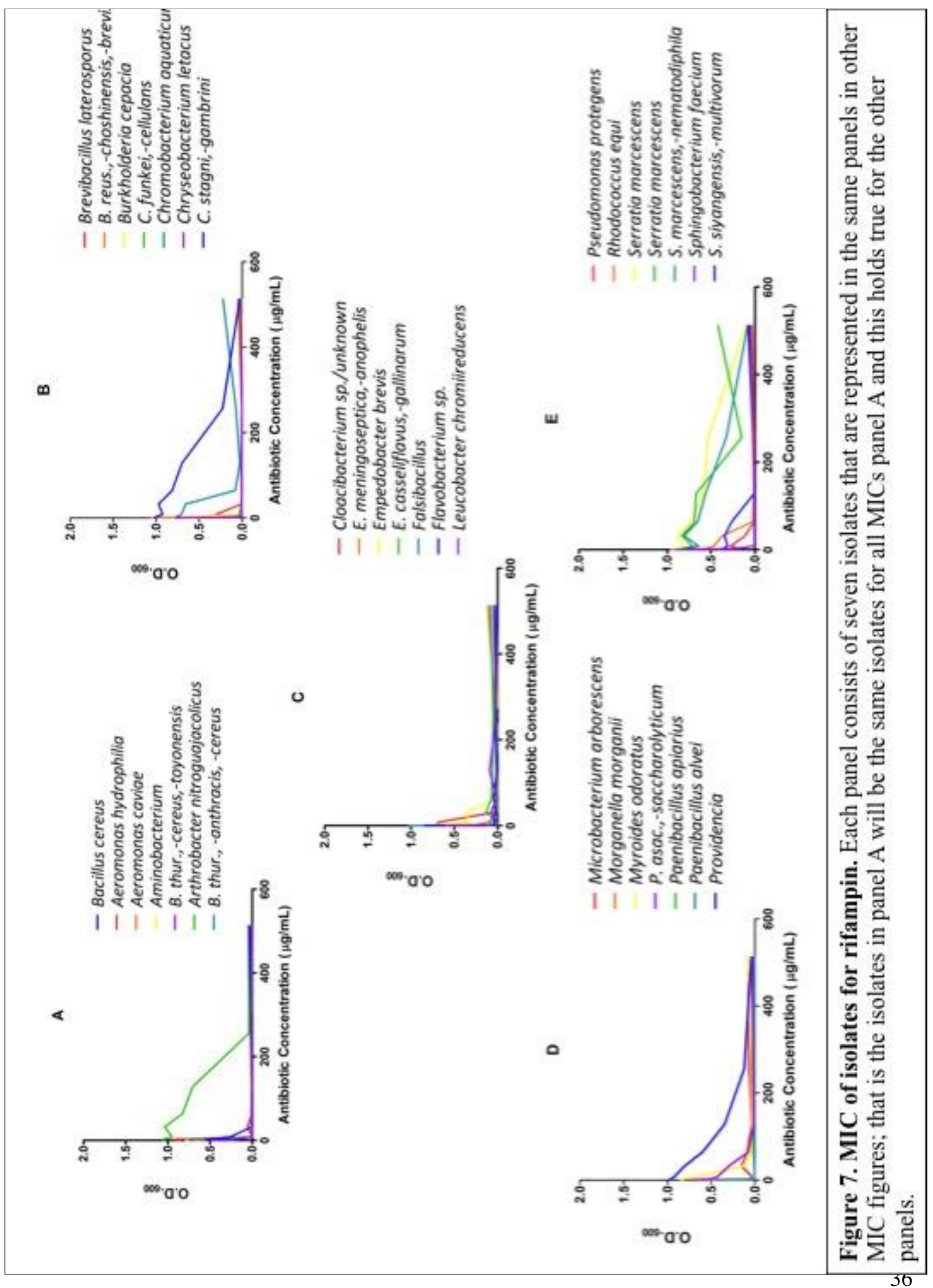




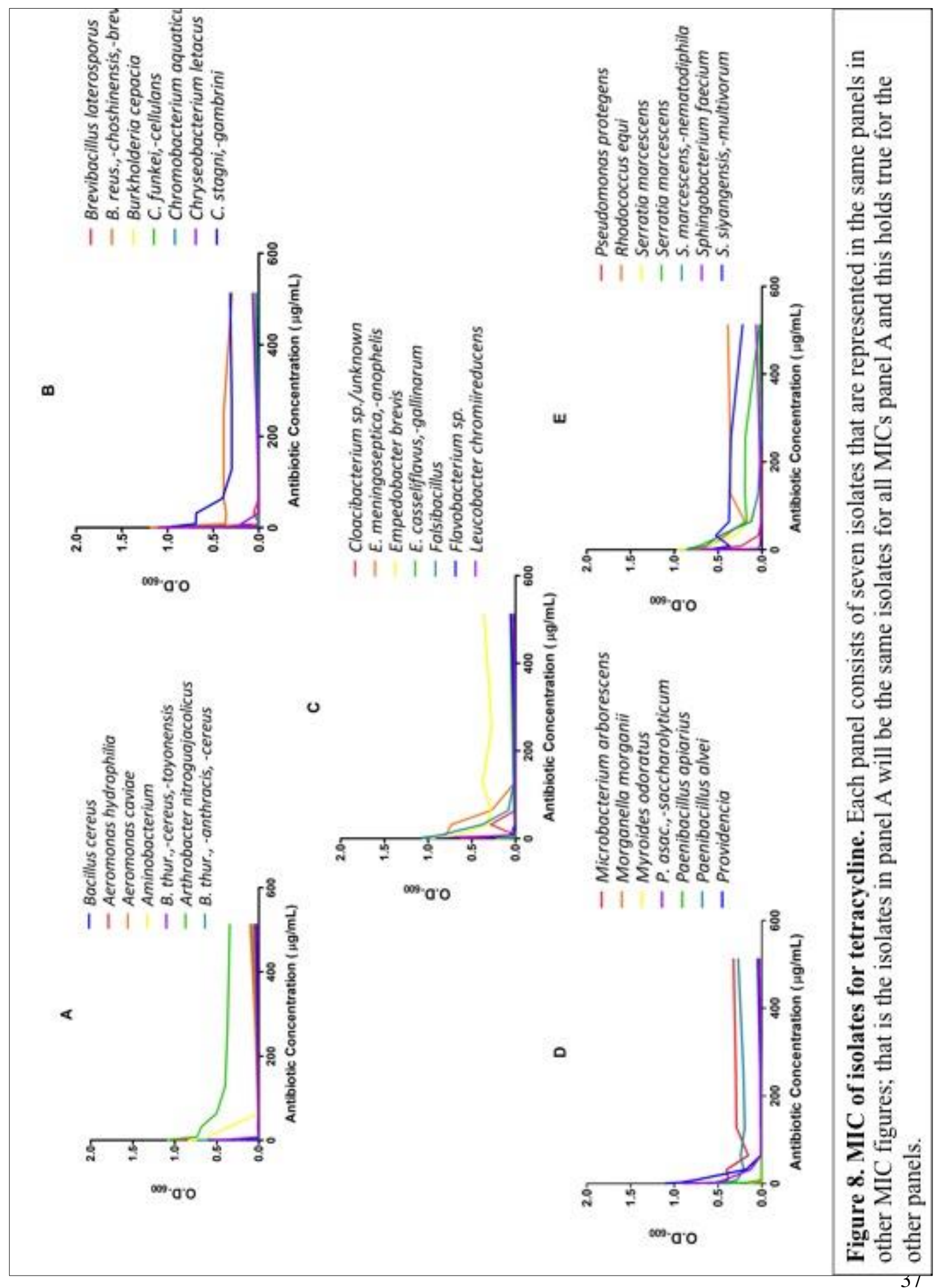




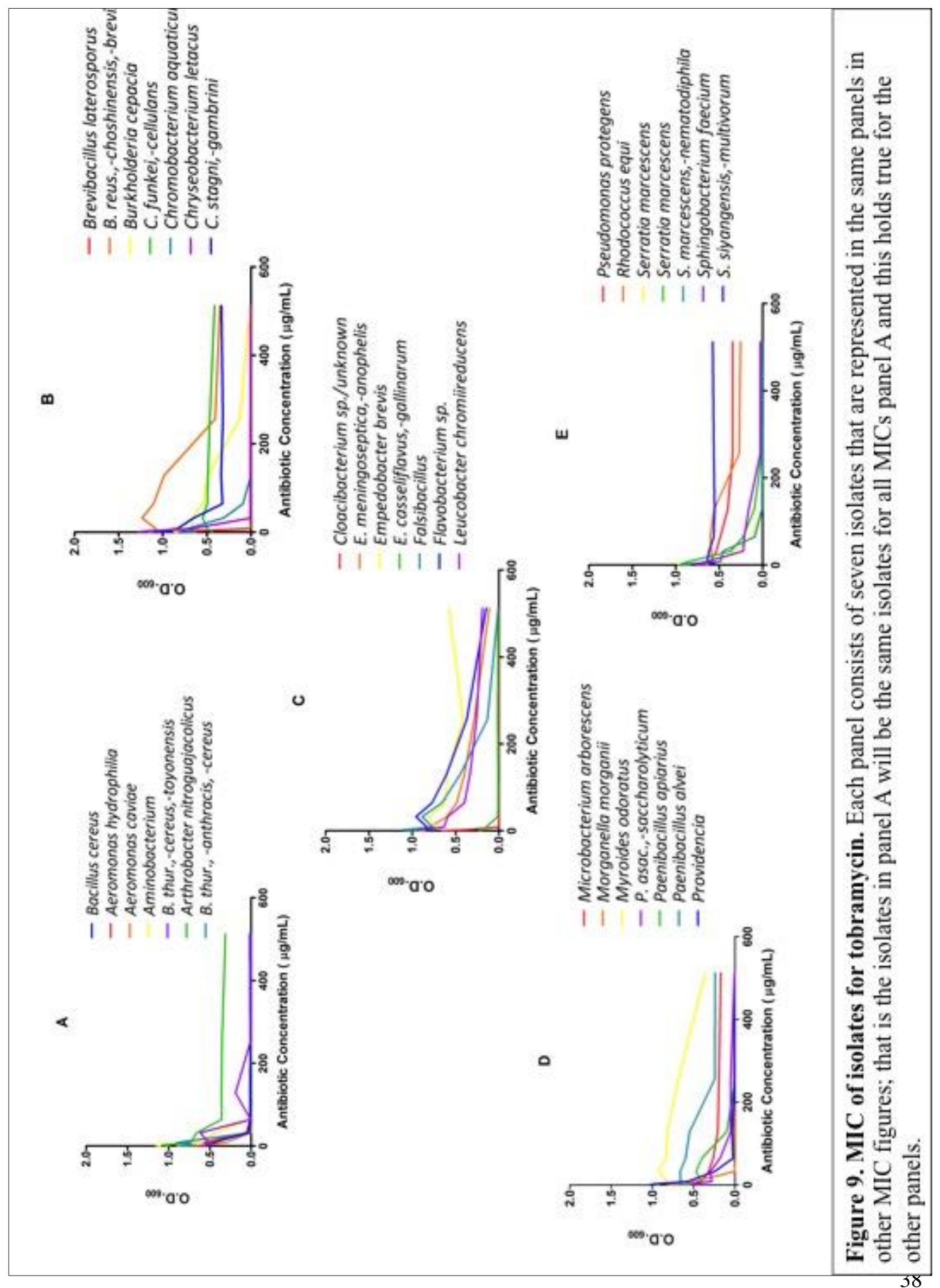




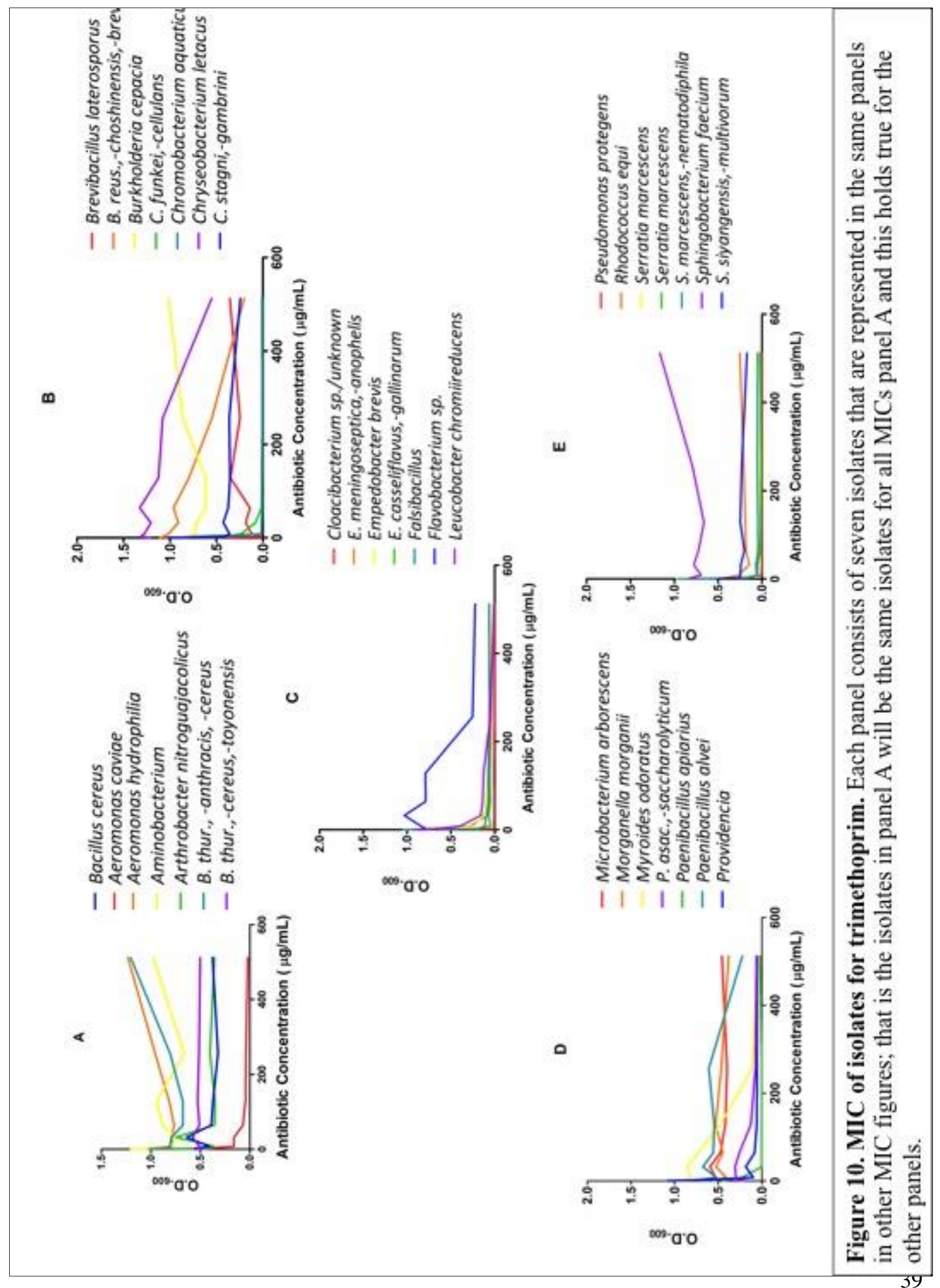


Tissue damage was assessed qualitatively and by comparing to control inoculations. In the onion maceration model, surprisingly only two strains, Myroides odoratus and Sphingobacterium faecium, showed some form of onion tissue maceration (Figure 11). In the lettuce maceration model, five genera of the twenty-seven showed some form of lettuce tissue maceration though it was not significant (Figure 11). The majority of the genera were unable to visibly infect or macerate either plant model revealing that most of these isolates are not pathogens of yellow onions and lettuce. The few that were able to macerate the plants were isolates collected from sources that did not involve plants with the exception of one, Sphingobacterium faecium. From this, plant-associated bacteria appear to be less likely to be plant pathogens. With the controls effectively macerating their respective plant model, the data could be interpreted that the plant itself may have been able to defend itself against the bacterial isolates or that the isolates lacked the appropriate cellulases or other enzymes that could lead to tissue destruction. It could also be that some of these isolates could serve a beneficial role to onion or lettuce plants; however, testing this was outside the scope and abilities of our research lab.

\section{Fungal and Bacterial Interaction Assay}

The goal of the fungal-bacterial interaction assay was to observe the microbial interaction between the representative isolates and the two fungi, A. fumigatus and C. albicans. The hypothesis of this assay was that the fungi were capable of outcompeting or inhibiting some of the isolates. To observe if there is a microbial interaction between the fungi and bacteria, both microbes were cross-streaked as described in Materials and Methods section and depicted in Supplementary Figure 5. The bacterial isolates showed variable responses to the fungi when 


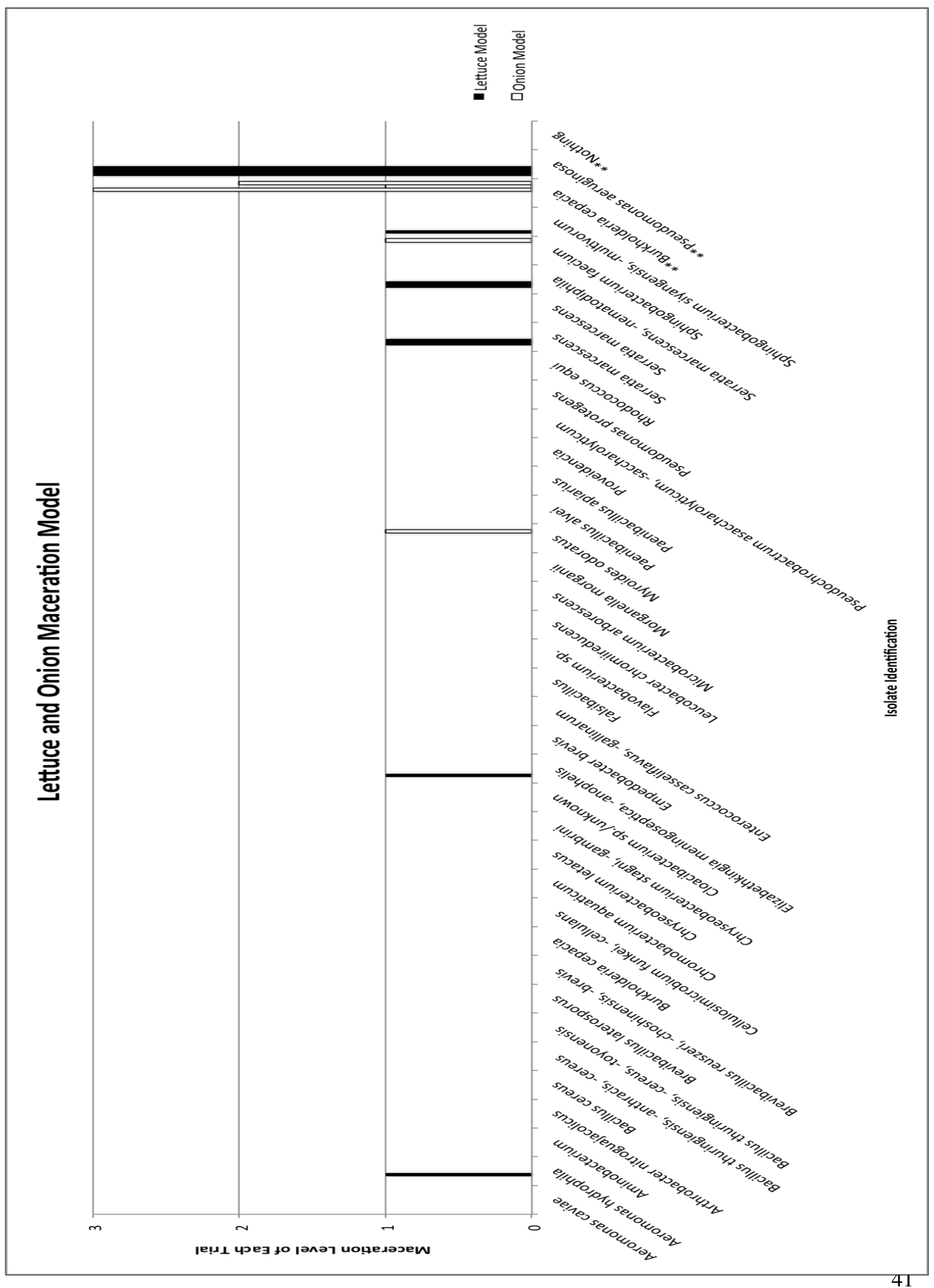


streaked in different orders (i.e. first or second). Approximately half of the isolates were unable to outcompete or inhibit the fungus A. fumigatus when the fungus was streaked first. When the bacterium was streaked first, only six isolates were unable to outcompete the fungus (Figure 12).

To interpret this graph, an example is given: Falsibacillus was able to outcompete the $A$. fumigatus when the bacterium was streaked first but unable to outcompete the fungus when the bacterium was streaked second. Approximately more than half of the isolates were able to outcompete the fungus Candida albicans regardless of the order of microbial streaking (Figure 13). It appeared that in some microbial interactions, the order of placement determines the microbial competitiveness. Of the isolates outcompeted by A. fumigatus, most of the isolates were Gram-positive. Of the isolates outcompeted by $C$. albicans, most of the isolates were Gram-negative. This may reveal that some fungi are more target-specific in regards to bacteiral inhibition.

\section{Antibiotic Single Carbon Source Assay}

In a study recently published, researchers identified that some soil bacteria could not only tolerate high levels of antibiotics but could consume them as a carbon source [9]. They identified these organisms by plating them on a solid medium containing salts and an antibiotic. To determine whether the isolates collected in this study could consume antibiotics in a similar manner, we struck our isolates on a minimum salts agar containing $0.5 \mathrm{~g} / \mathrm{L}$ of antibiotic $(0.1 \mathrm{~g} / \mathrm{L}$ for colistin). After growth at $37^{\circ} \mathrm{C}$, most isolates did not show the capability to consume most of the antibiotics (Table 4). 


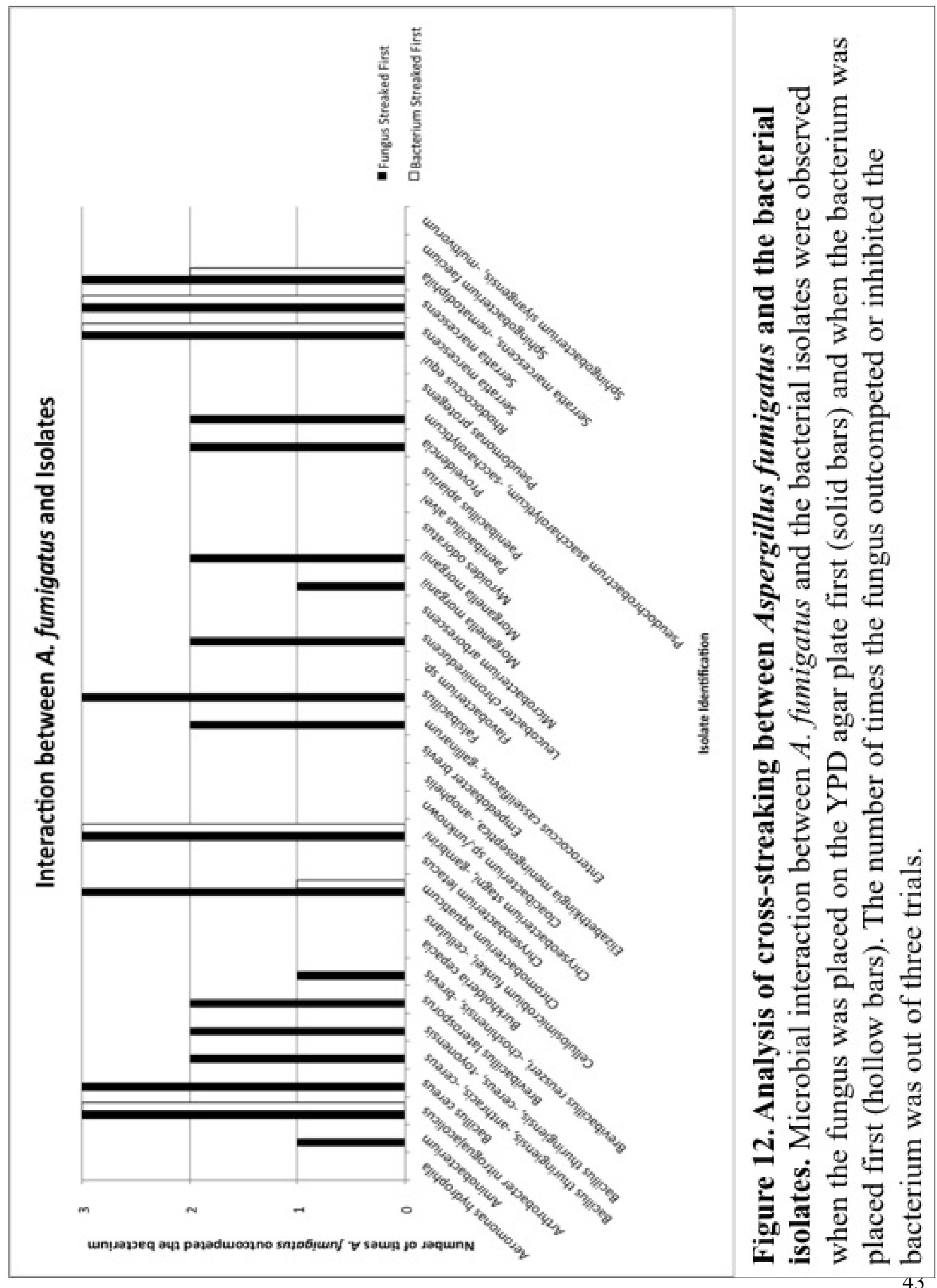




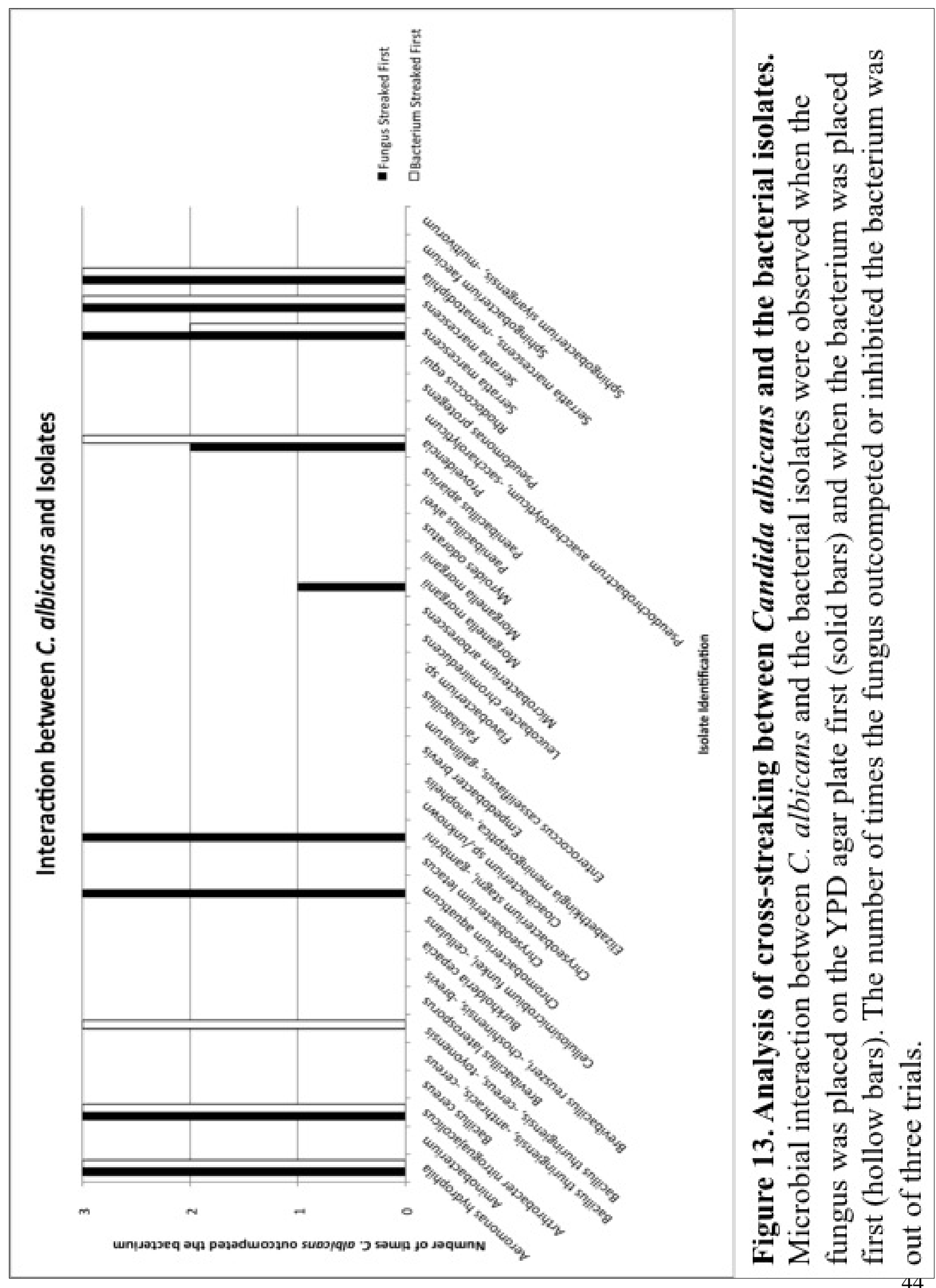


Colistin was the only antibiotic that could be consumed by most of the isolates (Table 4).

Kanamycin, penicillin, tobramycin, and trimethoprim were able to be consumed by less than half of the isolates. Chloramphenicol, nalidixic acid, rifampin, and tetracycline were unable to be consumed by any isolate with an exception of one or two isolates. This suggests that most of the isolates that are resistant to the antibiotics tolerate and detoxify these antibiotics but may not break them down for consumption as carbon sources. Since the concentration of colistin used was lower than the desired concentration (i.e. $0.10 \mathrm{~g} / \mathrm{L}$ instead of $0.50 \mathrm{~g} / \mathrm{L}$ ), this may explain the reason for most of the isolates being able to consume this particular antibiotic though the concentration is still high.

\begin{tabular}{|c|c|c|c|c|c|c|c|c|c|}
\hline \multirow[b]{2}{*}{ Bacterial Isolates } & \multicolumn{9}{|c|}{ Antibiotics } \\
\hline & Chloramphenicol & Colisitin & Kanamycin & Nalidixic Acid & \begin{tabular}{|l|} 
Penicillin \\
\end{tabular} & \begin{tabular}{|l|} 
Rifampin \\
\end{tabular} & Tetracycline & Tobramycin & Trimethoprim \\
\hline Aeromonas cavioe & $x$ & 2 & $x$ & $x$ & $\mathbf{x}$ & $x$ & $x$ & $x$ & 3 \\
\hline Aeromonas hydrophila & $\bar{x}$ & $x$ & $x$ & 3 & $\mathrm{x}$ & $\bar{x}$ & $x$ & $\mathrm{x}$ & $\bar{x}$ \\
\hline Aminobacterium & $\mathbf{x}$ & 3 & 2 & $x$ & 1 & $x$ & $x$ & $\mathbf{x}$ & 3 \\
\hline Arthrobacter nitroguajocolicus & $x$ & 2 & $x$ & $x$ & 3 & $x$ & 2 & $x$ & $x$ \\
\hline Bacillus cereus. & $x$ & 3 & 2 & $x$ & 3 & $x$ & $x$ & $x$ & 3 \\
\hline Bacillus thuringiensis, -anthrocis, -cereus & $\mathbf{x}$ & 3 & $\mathbf{x}$ & $x$ & $\mathbf{x}$ & $x$ & $\mathbf{x}$ & $x$ & 3 \\
\hline Bacillus thuringiensis, -cereus, -toyonensis & $x$ & 3 & 3 & $x$ & $x$ & $x$ & $x$ & 1 & 3 \\
\hline Brevibacillus loterasporus & $\mathbf{x}$ & $x$ & $x$ & $x$ & $x$ & $x$ & $x$ & $\mathbf{x}$ & $x$ \\
\hline Brevibacillus reuszeri, -choshinensis, -brevis & $x$ & $x$ & 3 & $x$ & 1 & $x$ & $\mathbf{x}$ & 3 & 2 \\
\hline Burkholderio cepocia & $x$ & 3 & 3 & $x$ & $x$ & $x$ & $x$ & 3 & $x$ \\
\hline Cellulosimicrobium funkei, -cellulans & $\mathbf{x}$ & $\mathrm{x}$ & $\mathbf{x}$ & $x$ & $x$ & $x$ & $\mathbf{x}$ & 3 & $x$ \\
\hline Chromobacterium aquaticum & $x$ & 3 & 2 & $x$ & $x$ & $x$ & $x$ & $x$ & $x$ \\
\hline Chryseobacterium letocus & $x$ & 3 & $x$ & $x$ & $x$ & $x$ & $x$ & $x$ & 3 \\
\hline Chryseabocterium stagni, -gambrini & $x$ & 3 & 3 & $x$ & 3 & $x$ & $x$ & 3 & $\bar{x}$ \\
\hline Cloacibacterium sp./unknown & $\mathbf{x}$ & $\mathrm{x}$ & $x$ & $x$ & $\mathbf{x}$ & $x$ & $x$ & $\mathbf{x}$ & $x$ \\
\hline Elizabethkingio meningoseptica, -anophelis & $x$ & 3 & 3 & $x$ & $x$ & $x$ & $\mathbf{x}$ & 3 & $x$ \\
\hline Empedabacter brevis & $\mathbf{x}$ & $x$ & 3 & $x$ & 3 & $\mathrm{x}$ & $\mathbf{x}$ & 3 & $x$ \\
\hline Enterococcus cosseliffavus, -gallinarum & $x$ & 3 & $\mathbf{x}$ & $x$ & 1 & $\mathrm{x}$ & $x$ & $x$ & $x$ \\
\hline Falsibocillus & $x$ & 3 & 3 & $x$ & $x$ & $x$ & $x$ & 3 & $x$ \\
\hline Flavobacterium sp. & $\mathbf{x}$ & 3 & $\mathbf{x}$ & $x$ & $\mathbf{x}$ & $x$ & $\mathbf{x}$ & $\mathbf{x}$ & 3 \\
\hline Leucobacter chromüreducens & $x$ & $\mathbf{x}$ & 3 & $x$ & $\mathbf{x}$ & $\mathrm{x}$ & $\mathbf{x}$ & 3 & $x$ \\
\hline Microbacterium arborescens & $\mathbf{x}$ & 3 & $\mathrm{x}$ & $\mathrm{x}$ & 1 & $x$ & $\mathbf{x}$ & $\mathbf{x}$ & 3 \\
\hline Morganella morganï & $\mathbf{x}$ & 3 & $\mathbf{x}$ & $\mathbf{x}$ & 1 & $\mathbf{x}$ & $\mathbf{x}$ & $\mathbf{x}$ & 2 \\
\hline Myroides adaratus & $\mathbf{x}$ & 3 & 2 & $\mathbf{x}$ & $\mathbf{x}$ & $\mathbf{x}$ & $\mathbf{x}$ & 3 & 3 \\
\hline Paenibacillus alvei & $\mathbf{x}$ & $\mathrm{x}$ & 3 & $\mathbf{x}$ & $\mathbf{x}$ & $\mathrm{x}$ & $\mathbf{x}$ & 3 & $\mathrm{x}$ \\
\hline Paenibacillus apiarius & $x$ & $\mathbf{x}$ & $\mathbf{x}$ & $x$ & $x$ & $x$ & $\mathbf{x}$ & $\mathbf{x}$ & $x$ \\
\hline Providencia & $\mathbf{x}$ & $x$ & $\mathrm{x}$ & 3 & 3 & $x$ & $\mathrm{x}$ & $\mathrm{x}$ & 3 \\
\hline Pseudochrobactrum asoccharolyticum, -saccharolyticum & $\mathbf{x}$ & 3 & 3 & $x$ & $\mathbf{x}$ & $x$ & $\mathbf{x}$ & $x$ & 3 \\
\hline Pseudomonos protegens & $x$ & 3 & 3 & $x$ & $x$ & $x$ & $x$ & 3 & $x$ \\
\hline Rhodococcus equit & $x$ & $x$ & 2 & $x$ & $x$ & $x$ & $x$ & $x$ & $x$ \\
\hline Serrotia marcescens & $x$ & 3 & $x$ & $x$ & 2 & $x$ & $x$ & $x$ & $x$ \\
\hline Serratia morcescens & $x$ & 3 & $x$ & $x$ & 3 & $x$ & $x$ & $x$ & $x$ \\
\hline Serrotia marcescens, -nematodiphila & $\mathbf{x}$ & 3 & $\mathrm{x}$ & $x$ & $\mathbf{x}$ & $x$ & $\mathrm{x}$ & $\mathbf{x}$ & $x$ \\
\hline Sphingobacterium foecium & $\mathbf{x}$ & $\mathbf{x}$ & 2 & $\mathbf{x}$ & $\mathbf{x}$ & $x$ & $\mathbf{x}$ & 3 & $x$ \\
\hline Sphingobacterium siyangensis, -multivorum & $\mathbf{x}$ & 3 & 3 & $x$ & $x$ & $x$ & $\mathbf{x}$ & 3 & $\mathrm{x}$ \\
\hline
\end{tabular}




\section{Discussion}

Surveying and collecting a small sample size of bacterial isolates from natural environments within Kentucky revealed a great diversity with at least ten genera containing known human pathogenic strains. The 27 genera discovered in this sample contained species resistant to colistin and tobramycin with a few resistant to carbenicillin, erythromycin, and irgasan. Though these bacterial isolates were collected from areas believed to have low human interactions, it can be noted that these resistant isolates are potentially able to transfer antibiotic resistance genes to non-resistant bacteria through means such as conjugation, transformation, and transduction. It should also be noted that even though some of these strains are not common human pathogens, even "non-pathogenic" or commensal bacteria maybe able to cause infections in susceptible hosts. As there are great number of people globally that are immunocompromised (e.g. HIV patients, patients undergoing chemotherapy, or patients who have recently had transplants and are chemically immunosuppressed) or have underlying conditions (e.g. severe diabetes, cystic fibrosis, severe burns) which tax the immune system, this work could reveal potential pathogens that may be difficult to eradicate. The more that is learned about these strains in advance, the better off the treatment could potentially be for those afflicted by these bacteria.

The 36 representative isolates of the 27 genera showed variable responses to each antibiotic in the MIC assay. The antibiotics that resulted in a high MIC can be inferred as ineffective against the tested isolates. Other antibiotics with intermediate to low MIC can be seen as having some form of efficacy in combating these isolates. Colistin, penicillin, tobramycin, and trimethoprim have shown to be less effective in combating the bacterial isolates.

Chloramphenicol, kanamycin, and nalidixic acid were effective against some bacterial strains, 
but not others. This data and similar data from other groups will hopefully allow antibiotic usage to be re-evaluated and increase development of new antibiotics. Re-evaluating the use of antibiotics involves changing antibiotic dosage or the use of other treatment protocols such as homeopathic treatments. New antibiotics could be developed by slightly changing the chemical structure of the antibiotic, which could increase the efficacy, or identifying novel antibiotics from natural or synthetic sources. It should be noted that the MIC assay was done with only single antibiotics; testing with a combination of antibiotics could lead to synergistic effects of the antibiotics.

The bacterial isolates showed little capability of infecting the plant models. This could be due to the plant's innate ability to fend off the bacterial invasion or a lack of virulence determinants specific for plants in the bacteria. Plants and bacteria have known symbiotic relationships, for example nitrogen-fixing bacteria that provide ammonia to plants and receive carbon compounds in return. When the interaction between the two is pathogenic (parasitic), plants have developed defense mechanisms against plant pathogenic bacteria through evolution. One unique mechanism that evolved in plants for protection was the production of specialized metabolites otherwise known as phytochemicals that convey antimicrobial properties [30]. In the detection of a bacterial invasion (inoculation sites), the plant may release the phytochemical to defend itself. On the other hand, the isolates may not be pathogenic against the two plant models and could be neutral or plant beneficial bacteria such as nitrogen-fixing bacteria. Either one of the two reasons (plant defenses or lack of plant virulence by bacteria) could explain why the majority of the plant samples were unaffected by the inoculation of the bacterial isolates; against known plant pathogens, the onion peels and lettuce leaves were effectively macerated. From the plant models, it could be seen that the yellow onion and lettuce may have antibacterial 
phytochemicals to aid their defense against the bacterial invasions. These phytochemicals could be a source for antibiotic development [30].

The fungal-bacterial interaction showed that the pathogenic fungus A. fumigatus was able to inhibit or outcompete approximately half of the isolates (most of which were Gram-positive bacteria) while $C$. albicans was able to inhibit a few of the isolates (most of which were Gramnegative bacteria). A. fumigatus has been found to secrete antibacterial compounds which would explain the ability to inhibit half of the isolates [41]. C. albicans may also be able to inhibit the bacteria with antibacterial compounds. These compounds could be extracted and developed into antibiotics that are selective in terms of Gram stain (e.g. antibacterial compounds from $A$. fumigatus could be developed into antibiotics targeting Gram-positive bacteria). Certain fungi have been known to contain antibacterial compounds that have been extracted and developed into commonly used antibiotics such as penicillin from the fungus Penicillium [16].

Many isolates were unable to utilize most antibiotics as a sole carbon source, suggesting that resistance did not result in the catabolism of the antibiotic. Though most of the isolates were able to consume colistin, the concentration for colistin was much lower than the others (i.e. 0.10 $\mathrm{g} / \mathrm{L}$ instead of $0.50 \mathrm{~g} / \mathrm{L})$. Should this assay for colistin be repeated, colistin should be repeated with $0.50 \mathrm{~g} / \mathrm{L}$ concentration. Out of the isolates that were able to utilize the antibiotics, the majority of them were isolated from soil environmental niches. This is expected since the majority of antibiotic-producing microbes (e.g. Streptomyces species) are commonly found in soils; thus bacteria naturally found in soils will need to have resistance mechanisms but they do not have to include antibiotic consumption/breakdown in their defense arsenal.

When examining the most common genera found in this study, the most prevalent groups (i.e. Bacillus, Serratia, and Sphingobacterium) appeared to be highly resistant to the antibiotics 
colistin, kanamycin, penicillin, and trimethoprim, and they were capable of utilizing the antibiotics as a sole carbon source. In regards to the fungal-bacterial interaction, both Bacillus and Serratia are inhibited by A. fumigatus while Sphingobacterium was able to outcompete the fungus. In the case of $C$. albicans, only Serratia was inhibited. From this, though Bacillus and Serratia are insensitive to almost half of the antibiotics used, the fungi were able to inhibit the bacteria through secretion of antibacterial compounds. Since the most prevalent genera are found in all four environments (i.e. association with animals or fungi, plants, water, and soils), resistance could be spread easily to other neighboring bacteria. These specific antibiotic resistant bacteria can be suppressed (with the exception of Sphingobacterium) by A. fumigatus's antibacterial compound, which could make A. fumigatus a possible source of antibiotic development.

The main hypotheses of this project were that (i) these bacterial isolates would be resistant to a large collection of antibiotics, (ii) the bacterial isolates collected from soil environments would be able to consume some of the nine antibiotics as a carbon source, (iii) some bacterial isolates would be plant pathogens, and (iv) some bacterial isolates would be inhibited by antibacterial compounds produced by the fungi. From the assays, all hypotheses were strongly supported with the exception of one. The hypothesis that was not strongly supported was that some isolates were plant pathogens. Though some isolates showed plant tissue maceration, the data were not substantial enough to warrant the assignation of a plant pathogen (i.e. for most of them, either 0 or 1 replicate out of 3 showed mild tissue destruction). Though only a small sample number was collected, it can be generalized to the greater population of native bacteria within Kentucky to a certain extent. These bacteria are resistant to an abundant of common antibiotics and may be less susceptible to others. This continuous rise of 
increased resistance could spread to other non-resistant bacteria. With the discovery of plant models and fungal interaction capable of inhibiting the bacteria collected, sources of antibiotics could be discovered from these assays. Native bacteria within Kentucky have shown increasing resistance towards common antibiotics. Though microbial interaction (e.g. conjugation or fungalbacterial interaction) may increase the spread of antibiotic resistance, reevaluation of antibiotic usage and development of new antibiotics from potential sources (e.g. plant models and fungi secretion) may allow the healthcare to be one step ahead in the arms race against bacteria.

\section{Acknowledgements}

I would like to thank my mentor Dr. Deborah Yoder-Himes for guiding me through the process of completing my thesis. I would like to thank Dr. Himes for his introduction into the research project and his guidance, Dr. Mueller for his aid in preparing this thesis, and Drs. Remold and Worley for usage of lab equipment. I would like to thank Brad Clark, Mariam Ahmed, Lauren Barrett, Willow Dietsch, Lindsey Duffy, Harry Ghooray, Charlie Keown, Trevor Loomis, Devin McBride, Jimmy Mey, Emily Ostrowski, Nick Seibold, Jae Seo, Ethan Shelton, Jacob Trimble, and Abi Zhang for their assistance in collecting all bacterial isolates in Kentucky and identifying approximately half of the isolates and performing the onion maceration model. I would like to again thank Devin McBride for her assistance in finishing the onion maceration model for the remaining half of the isolates. I would like to thank Eric Curtsinger for his assistance in identifying the remaining half of the isolates. I would also like to thank the University of Louisville Department of Biology and College of Arts and Sciences for funding that supported this work. 


\section{References}

1. Altschul, S. F., Gish, W., Miller, W., Myers, E. W., and Lipman, D. J. (1990) Basic local alignment search tool. J Mol Biol 215, 403-410

2. Andersson, D. I., and Hughes, D. (2010) Antibiotic resistance and its cost: is it possible to reverse resistance? Nat Rev Microbiol 8, 260-271

3. Arias, C. A., and Murray, B. E. (2009) Antibiotic-resistant bugs in the 21st century--a clinical super-challenge. $N$ Engl J Med 360, 439-443

4. Bennett, P. M. (2008) Plasmid encoded antibiotic resistance: acquisition and transfer of antibiotic resistance genes in bacteria. Br J Pharmacol 153 Suppl 1, S347-357

5. Beringer, P. (2001) The clinical use of colistin in patients with cystic fibrosis. Curr Opin Pulm Med 7, 434-440

6. Brogden, K. A., and Guthmiller, J. M. (2002) Polymicrobial Diseases, ASM Press, Washington D.C.

7. Brogden, R. N., Pinder, R. M., Sawyer, P. R., Speight, T. M., and Avery, G. S. (1976) Tobramycin: a review of its antibacterial and pharmacokinetic properties and therapeutic use. Drugs 12, 166-200

8. Cole, J. R., Wang, Q., Fish, J. A., Chai, B., McGarrell, D. M., Sun, Y., Brown, C. T., Porras-Alfaro, A., Kuske, C. R., and Tiedje, J. M. (2014) Ribosomal Database Project: data and tools for high throughput rRNA analysis. Nucleic Acids Res 42, D633-642

9. Dantas, G., Sommer, M. O., Oluwasegun, R. D., and Church, G. M. (2008) Bacteria subsisting on antibiotics. Science 320, 100-103

10. Fedorenko, V., Genilloud, O., Horbal, L., Marcone, G. L., Marinelli, F., Paitan, Y., and Ron, E. Z. (2015) Antibacterial Discovery and Development: From Gene to Product and Back. Biomed Res Int 2015, 591349

11. Flume, P. A., Mogayzel, P. J., Jr., Robinson, K. A., Goss, C. H., Rosenblatt, R. L., Kuhn, R. J., Marshall, B. C., and Clinical Practice Guidelines for Pulmonary Therapies, C. (2009) Cystic fibrosis pulmonary guidelines: treatment of pulmonary exacerbations. Am J Respir Crit Care Med 180, 802-808

12. Furtado, N. A., Said, S., Ito, I. Y., and Bastos, J. K. (2002) The antimicrobial activity of Aspergillus fumigatus is enhanced by a pool of bacteria. Microbiol Res 157, 207-211 
13. Geller, D. E., Konstan, M. W., Smith, J., Noonberg, S. B., and Conrad, C. (2007) Novel tobramycin inhalation powder in cystic fibrosis subjects: pharmacokinetics and safety. Pediatr Pulmonol 42, 307-313

14. Gillespie, J. J., Wattam, A. R., Cammer, S. A., Gabbard, J. L., Shukla, M. P., Dalay, O., Driscoll, T., Hix, D., Mane, S. P., Mao, C., Nordberg, E. K., Scott, M., Schulman, J. R., Snyder, E. E., Sullivan, D. E., Wang, C., Warren, A., Williams, K. P., Xue, T., Yoo, H. S., Zhang, C., Zhang, Y., Will, R., Kenyon, R. W., and Sobral, B. W. (2011) PATRIC: the comprehensive bacterial bioinformatics resource with a focus on human pathogenic species. Infect Immun 79, 4286-4298

15. Gullberg, E., Cao, S., Berg, O. G., Ilback, C., Sandegren, L., Hughes, D., and Andersson, D. I. (2011) Selection of resistant bacteria at very low antibiotic concentrations. PLoS Pathog 7, e1002158

16. Hare, R. (1982) New light on the history of penicillin. Med Hist 26, 1-24

17. Hongoh, Y., Yuzawa, H., Ohkuma, M., and Kudo, T. (2003) Evaluation of primers and PCR conditions for the analysis of $16 \mathrm{~S}$ rRNA genes from a natural environment. FEMS Microbiol Lett 221, 299-304

18. Jacobs, J. L., Fasi, A. C., Ramette, A., Smith, J. J., Hammerschmidt, R., and Sundin, G. W. (2008) Identification and onion pathogenicity of Burkholderia cepacia complex isolates from the onion rhizosphere and onion field soil. Appl Environ Microbiol 74, $3121-3129$

19. Kang, C. I., Kim, S. H., Park, W. B., Lee, K. D., Kim, H. B., Kim, E. C., Oh, M. D., and Choe, K. W. (2005) Bloodstream infections caused by antibiotic-resistant gram-negative bacilli: risk factors for mortality and impact of inappropriate initial antimicrobial therapy on outcome. Antimicrob Agents Chemother 49, 760-766

20. Konstan, M. W., Flume, P. A., Kappler, M., Chiron, R., Higgins, M., Brockhaus, F., Zhang, J., Angyalosi, G., He, E., and Geller, D. E. (2011) Safety, efficacy and convenience of tobramycin inhalation powder in cystic fibrosis patients: The EAGER trial. J Cyst Fibros 10, 54-61

21. Li, J., Nation, R. L., Milne, R. W., Turnidge, J. D., and Coulthard, K. (2005) Evaluation of colistin as an agent against multi-resistant Gram-negative bacteria. Int J Antimicrob Agents 25, 11-25

22. Li, J., Nation, R. L., Turnidge, J. D., Milne, R. W., Coulthard, K., Rayner, C. R., and Paterson, D. L. (2006) Colistin: the re-emerging antibiotic for multidrug-resistant Gramnegative bacterial infections. Lancet Infect Dis 6, 589-601 
23. MacLeod, D. L., Nelson, L. E., Shawar, R. M., Lin, B. B., Lockwood, L. G., Dirk, J. E., Miller, G. H., Burns, J. L., and Garber, R. L. (2000) Aminoglycoside-resistance mechanisms for cystic fibrosis Pseudomonas aeruginosa isolates are unchanged by longterm, intermittent, inhaled tobramycin treatment. J Infect Dis 181, 1180-1184

24. Magiorakos, A. P., Srinivasan, A., Carey, R. B., Carmeli, Y., Falagas, M. E., Giske, C. G., Harbarth, S., Hindler, J. F., Kahlmeter, G., Olsson-Liljequist, B., Paterson, D. L., Rice, L. B., Stelling, J., Struelens, M. J., Vatopoulos, A., Weber, J. T., and Monnet, D. L. (2012) Multidrug-resistant, extensively drug-resistant and pandrug-resistant bacteria: an international expert proposal for interim standard definitions for acquired resistance. Clin Microbiol Infect 18, 268-281

25. Martinez, J. L. (2008) Antibiotics and antibiotic resistance genes in natural environments. Science 321, 365-367

26. Moffatt, J. H., Harper, M., Harrison, P., Hale, J. D., Vinogradov, E., Seemann, T., Henry, R., Crane, B., St Michael, F., Cox, A. D., Adler, B., Nation, R. L., Li, J., and Boyce, J. D. (2010) Colistin resistance in Acinetobacter baumannii is mediated by complete loss of lipopolysaccharide production. Antimicrob Agents Chemother 54, 4971-4977

27. Moran, G. P., Coleman, D. C., and Sullivan, D. J. (2011) Candida albicans versus Candida dubliniensis: Why Is C. albicans More Pathogenic? International Journal of Microbiology 2012, 1-7

28. Peleg, A. Y., Hogan, D. A., and Mylonakis, E. (2010) Medically important bacterialfungal interactions. Nat Rev Microbiol 8, 340-349

29. Poole, K. (2005) Aminoglycoside resistance in Pseudomonas aeruginosa. Antimicrob Agents Chemother 49, 479-487

30. Prithiviraj, B., Weir, T., Bais, H. P., Schweizer, H. P., and Vivanco, J. M. (2005) Plant models for animal pathogenesis. Cell Microbiol 7, 315-324

31. Procopio, R. E., Silva, I. R., Martins, M. K., Azevedo, J. L., and Araujo, J. M. (2012) Antibiotics produced by Streptomyces. Braz J Infect Dis 16, 466-471

32. Ratjen, F., Rietschel, E., Kasel, D., Schwiertz, R., Starke, K., Beier, H., van Koningsbruggen, S., and Grasemann, H. (2006) Pharmacokinetics of inhaled colistin in patients with cystic fibrosis. J Antimicrob Chemother 57, 306-311

33. Renwick, M. J., Brogan, D. M., and Mossialos, E. (2016) A systematic review and critical assessment of incentive strategies for discovery and development of novel antibiotics. J Antibiot (Tokyo) 69, 73-88

34. S, W. S. Y., Li, J., Patel, K., Wilson, J. W., Dooley, M. J., George, J., Clark, D., Poole, S., Williams, E., Porter, C. J., Nation, R. L., and McIntosh, M. P. (2014) Pulmonary and 
systemic pharmacokinetics of inhaled and intravenous colistin methanesulfonate in cystic fibrosis patients: targeting advantage of inhalational administration. Antimicrob Agents Chemother 58, 2570-2579

35. Spellberg, B., Guidos, R., Gilbert, D., Bradley, J., Boucher, H. W., Scheld, W. M., Bartlett, J. G., Edwards, J., Jr., and Infectious Diseases Society of, A. (2008) The epidemic of antibiotic-resistant infections: a call to action for the medical community from the Infectious Diseases Society of America. Clin Infect Dis 46, 155-164

36. Sperandio, F. F., Huang, Y. Y., and Hamblin, M. R. (2013) Antimicrobial photodynamic therapy to kill Gram-negative bacteria. Recent Pat Antiinfect Drug Discov 8, 108-120

37. Starkey, M., and Rahme, L. G. (2009) Modeling Pseudomonas aeruginosa pathogenesis in plant hosts. Nat Protoc 4, 117-124

38. Svahn, K. S., Goransson, U., El-Seedi, H., Bohlin, L., Larsson, D. G., Olsen, B., and Chryssanthou, E. (2012) Antimicrobial activity of filamentous fungi isolated from highly antibiotic-contaminated river sediment. Infect Ecol Epidemiol 2

39. Tenover, F. C. (2006) Mechanisms of antimicrobial resistance in bacteria. Am J Med 119, S3-10; discussion S62-70

40. Ventola, C. L. (2015) The antibiotic resistance crisis: part 1: causes and threats. P T 40, 277-283

41. Waksman, S. A., and Geiger, W. B. (1944) The Nature of the Antibiotic Substances Produced by Aspergillus fumigatus. J Bacteriol 47, 391-397

42. Wang, Q., Garrity, G. M., Tiedje, J. M., and Cole, J. R. (2007) Naive Bayesian classifier for rapid assignment of rRNA sequences into the new bacterial taxonomy. Appl Environ Microbiol 73, 5261-5267 


\section{Appendix}

\section{Supplemental Figures II. Supplemental Tables}




\section{Supplementary Figures}




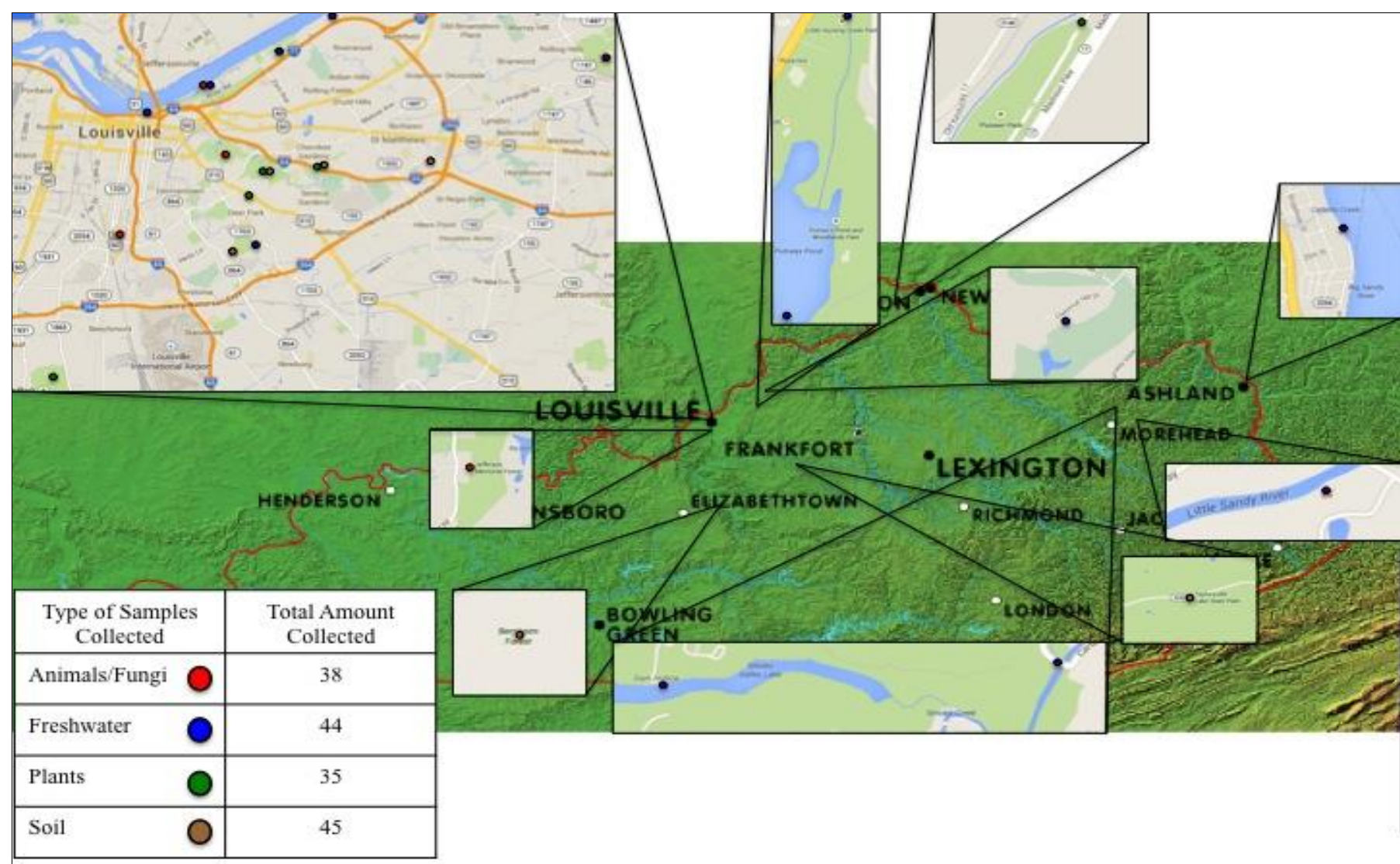

Supplementary Figure 1. Sampling Locations in Kentucky A variety of samples collected from various sites in Kentucky in early July. Samples

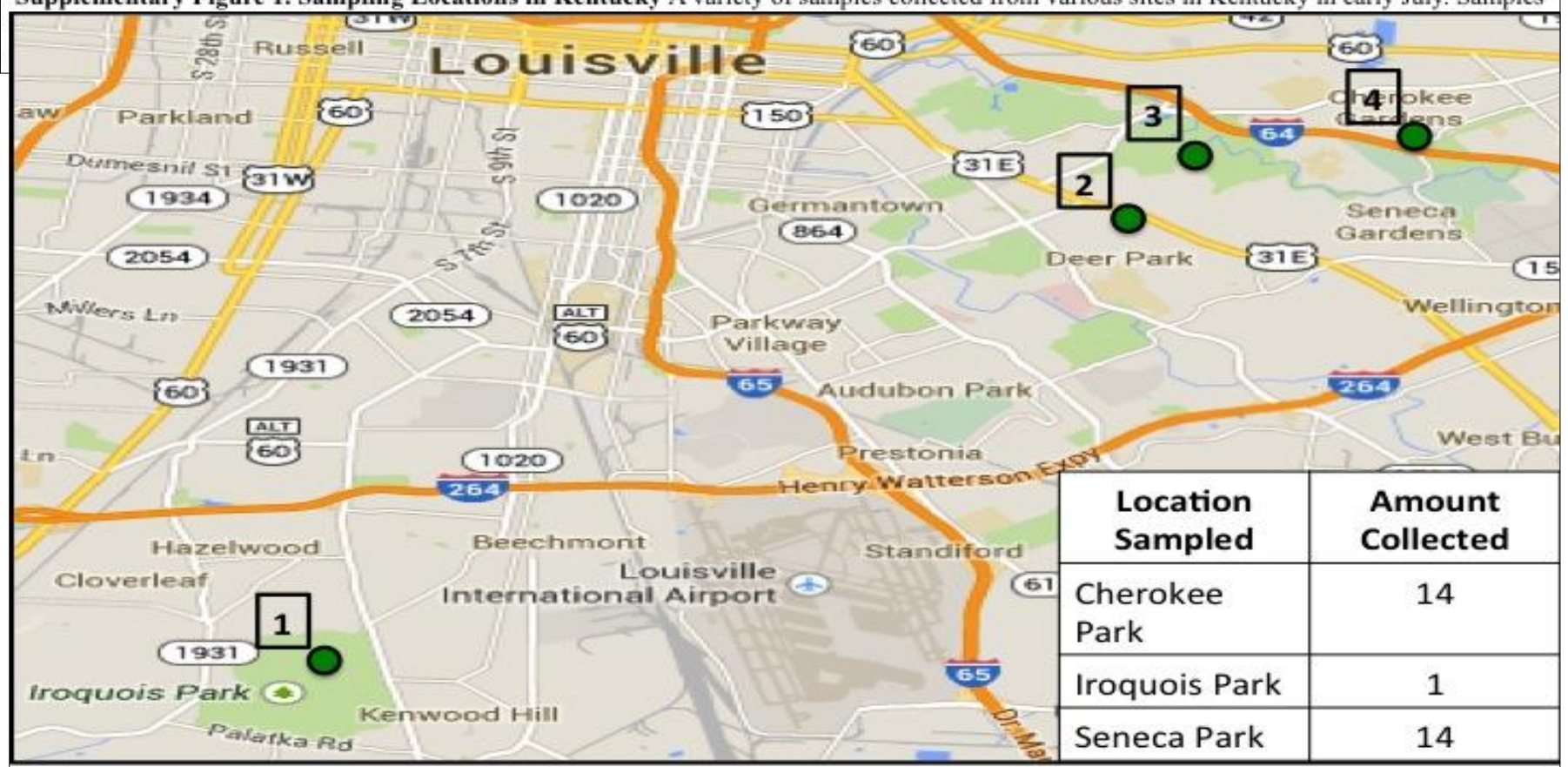

- The green dots represent sample sites

Supplementary Figure 2. Sampling Locations in Louisville. Samples associated with plant life were collected at distinct locations in Louisville in early June. Two of the samples were collected from vegetables bought at Kroger. Samples were collected at different times of the day, temperature, and heights relative to the ground. 


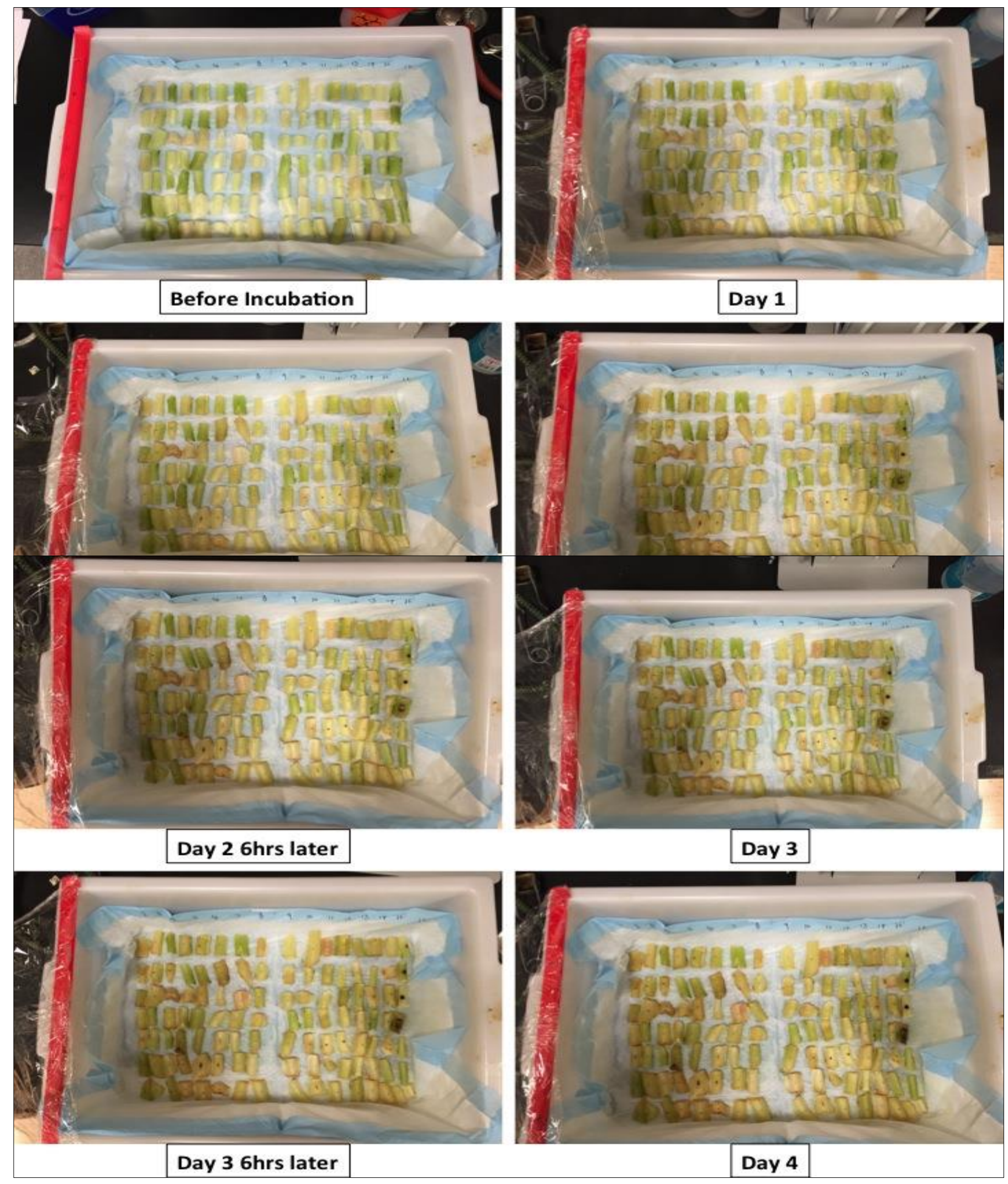

Supplementary Figure 4. Lettuce Infection Assay. Photos of the lettuce cores over a period of 5 days with photos taken in $6 \mathrm{hrs}$ and $12 \mathrm{hrs}$ post infection. Controls are the farthest right column of lettuce cores with the top four cores (black circles) as the positive controls and the bottom three (red circles) as the negative controls. 

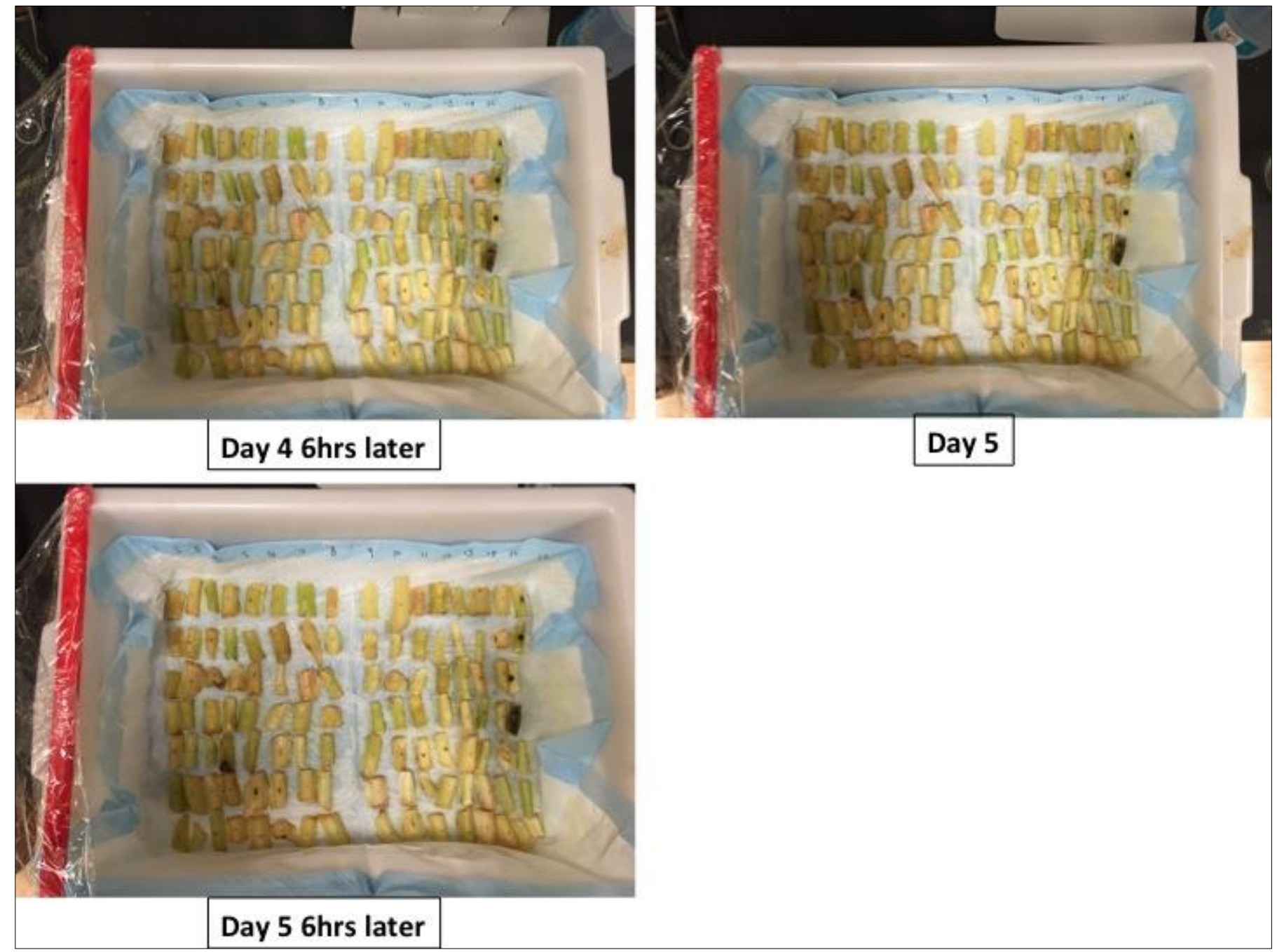

Supplementary Figure 4 continued. Lettuce Infection Assay. Photos of the lettuce cores over a period of 5 days with photos taken in $6 \mathrm{hrs}$ and $12 \mathrm{hrs}$ post infection. Controls are the farthest right column of lettuce cores with the top four cores (black circles) as the positive controls and the bottom three (red circles) as the negative controls. 


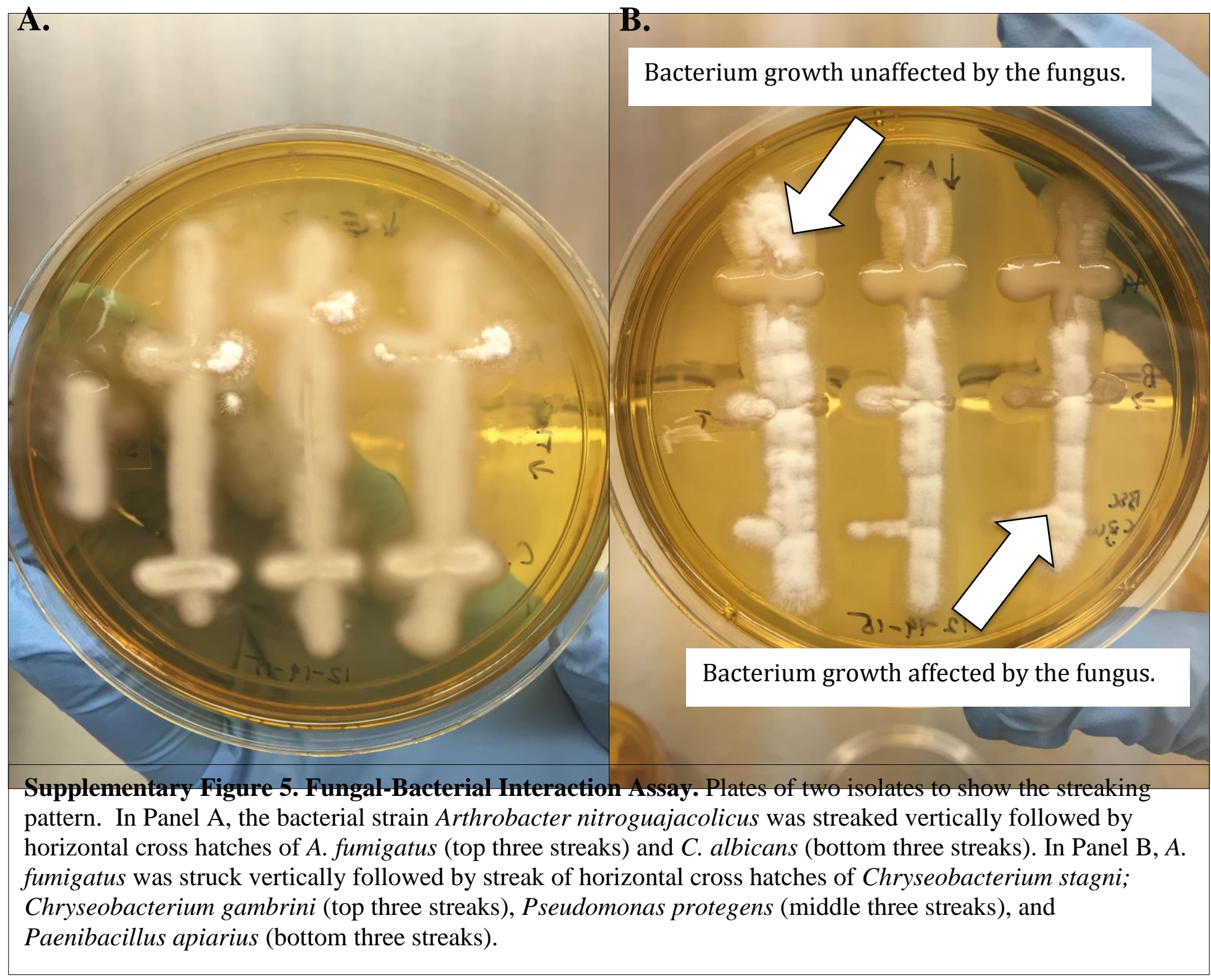




\section{Supplementary Tables}




\begin{tabular}{|c|c|c|}
\hline Bacterial Isolates & Abbreviations & MIC Abbreviations \\
\hline 1. Aeromonas cavioe & Aeromonas caviae & Aeromonas caviae \\
\hline 2. Aeromonas hydrophila & Aeromonas hydrophila & Aeromonas hydrophila \\
\hline 3. Aminobacterium & Aminobocterium & Aminobacterium \\
\hline 4. Arthrobacter nitroguajacolicus & Arthrobocter nitroguajacolicus & Arthrobacter nitroguajacolicus \\
\hline 5. Bacillus cereus & Bacillus cereus & Bacillus cereus \\
\hline 5. Bocillus thuringiensis, Bacillus anthrocis, Bacillus cereus & Bacillus thuringiensis, -anthrocis, -cereus & B. thur., -onthrocis, -cereus \\
\hline 7. Bocillus thuringiensis; Bocillus cereus; Bocilius toyonensis & Bacillus thuringiensis, -cereus, -toyonensis & B. thur.,-cereus,-toyonensis \\
\hline 8. Brevibacillus iaterosporus & Brevibacillus loterosporus & Brevibacillus laterosporus \\
\hline 9. Brevibacillus reuszen;, Brevibacillus choshinensis; Brevibacillus brevis & Brevibacillus reuszeri, -choshinensis, -brevis & B. reus,-choshinensis,-brevis \\
\hline 10. Burkhoideria cepacio & Burkholderia cepacio & Burkholderio cepacia \\
\hline 11. Cellulosimicrobium funkei, Cellulosimicrobium cellulans & Celluiosimicrobium funkei, -cellulans & C. funkei,-celluians \\
\hline 12. Chromobocterium aquoticum & Chromobacterium aquaticum & Chromobacterium aquoticum \\
\hline 13. Chryseobocterium letacus & Chryseobacterium letacus & Chryseobacterium letocus \\
\hline 14. Chryseobocterium stogni; Chryseobocterium gambrini & Chryseobacterium stagni, -gambrini & C. stagni,gambrini \\
\hline 15. Cloacibocterium sp./unknown & Cloocibacterium sp./unknown & Cloocibacterium sp./unknown \\
\hline 16. Elizabethkingia meningoseptico; Elizabethkingio anophelis & Elizabethkingia meningoseptica, -anophelis & E. meningoseptico, anophelis \\
\hline 17. Empedobacter brevis & Empedobocter brevis & Empedobacter brevis \\
\hline 18. Enterococcus casseliflavus; Enterococcus gallinarum & Enterococcus casseliflovus, gallinarum & E. casseliflavus, gallinarum \\
\hline 19. Falsibacillus & Falsibacillus & Falsibacillus \\
\hline 20. Flavobacterium sp. & Flavobacterium sp. & Flavobocterium sp. \\
\hline 21. Leucobocter chromiireducens & Leucobocter chromireducens & Leucobacter chromireducens \\
\hline 22. Microbocterium arborescens & Microbacterium arborescens & Microbacterium arborescens \\
\hline 23. Morganella morganif & Morganellia morganii & Morganellio morganii \\
\hline 24. Myroides odoratus & Myroides odoratus & Myroides odorotus \\
\hline 25. Poenibocilius alvei & Poenibacillus alvei & Poenibocillus alvei \\
\hline 26. Poenibocilius apiarius & Paenibacillus opiarius & Poenibocillus apiarius \\
\hline 27. Proveidencia & Proveidencia & Proveidencia \\
\hline 28. Pseudochroboctrum asoccharolyticum; Pseudochroboctrum soccharolyticum & Pseudochrobactrum asaccharolyticum, -soccharolyticum & P. asoc.,-soccharolyticum \\
\hline 29. Pseudomonas protegens & Pseudomonas protegens & Pseudomonas protegens \\
\hline 30. Rhodococcus equi & Rhodococcus equi & Rhodococcus equi \\
\hline 31. Serratia marcescens & Serrotia marcescens & Serrotia marcescens \\
\hline 32. Serrotia marcescens & Serrotia marcescens & Serrotia marcescens \\
\hline 33. Serratia marcescens; Serrotia nematodiphila & Serrotia marcescens, nemotodiphila & S. marcescens, nematodiphila \\
\hline 34. Sphingobocterium foecium & Sphingobocterium foecium & Sphingobacterium foecium \\
\hline 35. Sphingobocterium siyangensis; Sphingobocterium multivorum & Sphingobacterium siyangensis, -multivorum & S. siyangensis,-multivorum \\
\hline
\end{tabular}

